Ewa Barylewska-Szymańska

Muzeum Gdańska, Instytut Historii PAN

ORCID: 0000-0003-0887-3714

\title{
Działalność architekta Friedricha Fischera (1879-1944) w Gdańsku i Sopocie
}

\author{
https://doi.org/10.26881/porta.2021.20.05
}

Słowa kluczowe: Friedrich Fischer, Wolne Miasto Gdańsk, Urząd Budownictwa Naziemnego, konserwator zabytków architektury, Wyższa Szkoła Techniczna w Gdańsku

Keywords: Friedrich Fischer, Free City of Gdańsk, Ground Construction Office, conservator of historical monuments, Technical University of Gdańsk

Friedrich Fischer był pierwszym kierownikiem Urzędu Budownictwa Naziemnego (Hochbauamt) i konserwatorem zabytków architektonicznych Wolnego Miasta Gdańska (Staatlicher Denkmalpfleger der Baukunst) ${ }^{1}$.

Badaczy architektury Fischer zajmuje obecnie przede wszystkim jako wykładowca architektury Wyższej Szkoły Technicznej². Natomiast jego dokonania jako prywatnego architekta, aktywność w Urzędzie Budownictwa Naziemnego, wkład w ochronę gdańskich zabytków i udział w opracowaniu Ustawy o ochronie zabytków i przyrody (Gesetz betreffend den Denkmal- und Naturschutz) dla obszaru Wolnego Miasta Gdańska z 1923 r. są nieobecne we współczesnej literaturze naukowej. Przedmiotem artykułu będą dokonania Fischera jako prywatnego architekta na terenie Gdańska i Sopotu, jego działalność jako urzędnika administracji budowlanej oraz konserwatora zabytków na terenie Wolnego Miasta Gdańska.

Friedrich Wilhelm Heinrich Fischer urodził się w Elblągu 27 marca 1879 r. w rodzinie Friedricha Fischera, wyższego inżyniera (Oberingenieur) w Stoczni

1 W 2016 r. opublikowano artykuł, zob. Ewa Barylewska-Szymańska, Friedrich Fischer und die Architekturdenkmalpflege in den Anfängen der Freien Stadt Danzig [w:] Entdecken - Erforschen - Bewahren. Beiträge zur Kunstgeschichte und Denkmalpflege. Festgabe für Sibylle Badstübner-Gröger zum 12. Oktober 2015, Hg. Camilla Badstübner-Kizik, Edmund Kizik, Berlin 2016, s. 286-295. Obecnie został on zmieniony, uzupełniony i rozszerzony o nowe zagadnienia.

2 Katja Bernhardt, Stil - Raum - Ordnung. Architekturlehre in Danzig 1904-1945, Berlin 2015, s. 88-89.

3 Z racji ograniczeń dotyczących objętości artykułu autorka była zmuszona zrezygnować z zamieszczenia szerszych odniesień do niemieckiej architektury omawianego tu okresu. 
Ewa Schichaua (Schichauwerft) ${ }^{4}$, i Hedwigi Fechter. W Elblągu odbył edukację, Barylewska-Szymańska uczył się m.in. w tamtejszym gimnazjum i gimnazjum realnym. W $1900 \mathrm{r}$. zdał egzamin maturalny. Przeszedł także szkolenie zawodowe w modelarni Stoczni Schichaua. Studia architektoniczne podjął w Wyższej Szkole Technicznej w Monachium (Technische Hochschule München), później przeniósł się do Karlsruhe (Technische Hochschule Karlsruhe) i Berlina-Charlottenburgu (Technische Hochschule Charlottenburg). Na tej ostatniej, prestiżowej uczelni złożył w listopadzie 1905 r. egzamin dyplomowy ${ }^{5}$. Do gdańskiej administracji budowlanej trafił w 1906 r. jako Regierungs-Baumeister. Rok później poślubił w Elblągu Ruth, córkę Paula Muscate. Egzaminy końcowe zdał na początku lipca $1910 \mathrm{r}$.

Fischer był równocześnie aktywny naukowo, już w styczniu 1910 r. obronił w gdańskiej Wyższej Szkole Technicznej rozprawę doktorską zatytułowaną Der Danziger Kirchenbau des 15. und 16. Jahrhunderts (Gdańskie budowle kościelne $z X V i X V I$ w. $)^{6}$. Rozprawa powstała pod opieką naukową prof. Karla Webera ${ }^{7}$. Praca liczyła 39 stron, co z dzisiejszego punktu widzenia wydaje się jedynie niewielkim studium, jednak wówczas taką objętość miały mniej więcej dysertacje powstające w miejscowej Wyższej Szkole Technicznej. Istotnym elementem

4 Dane biograficzne opracowano na podstawie Hans Reuther, Fischer, Friedrich Wilhelm Heinrich [w:] Neue Deutsche Biographie, Bd. 5, 1961, s. 185; http://www.deutsche-biographie. de/ppn135989744.html [dostęp: 12.06.2021]; Carl Wünsch, Fischer Friedrich Wilhelm Heinrich [w:] Altpreußische Biographie, Bd. 3, Hg. Kurt Forstreuter, Fritz Gause, Marburg-Lahn 1975, s. 904; Friedrich Lindau, Fischer, Friedrich Wilhelm Heinrich [w:] Saur. Allgemeines Künstler-Lexikon. Die bildenden Künstler aller Zeiten und Völker, Bd. 40, Hg. Günter Meißner, München 2004, s. 333; Willibald Reichertz: Ostdeutsche als Dozenten an der Technischen Hochschule Hannover (1831-1956), „Ostdeutsche Familienkunde” 2007, Jg. 55, Bd. 18, H. 3, s. 111; Bernhardt, Stil - Raum - Ordnung..., s. 88-89; Fischer Friederich, http://kulturportal-west-ost.eu/biographien/ fischer-friedrich-2 [dostęp: 12.06.2021]; Fischer, Friedrich Wilhelm Heinrich, http://www.glass-portal.privat.t-online.de/hs/a-f/fischer_friedrich.htm [dostęp: 12.06.2021].

5 Na temat rangi i znaczenia Wydziału Architektury Wyższej Szkoły Technicznej w Berlinie-Charlottenburgu wśród innych tego typu wydziałów na niemieckich uczelniach technicznych zob. Stefanie Fink, „Brausejahre” in Berlin. Die Architektenausbildung an der Technischen Hochschule Charlottenburg während der Kaiserzeit [w:] Nicht nur Bauhaus. Netzwerke der Moderne in Mitteleuropa / Not just Bauhaus. Networks of Modernity in Central Europe, red. Beate Störtkuhl, Rafał Makała, Berlin-Boston 2020 (Schriften des Bundesinstitutes für Kultur und Geschichte der Deutschen im östlichen Europa, Bd. 77), s. 40, 42.

6 Friedrich Fischer, Der Danziger Kirchenbau des 15. und 16. Jahrhunderts (Diss. THD), Danzig 1910; Bücherschau. 10. Verzeichnis der wissenschaftlichen Abhandlungen zur Erlangung der Würde eines Doktor-Ingenieurs, „Zentralblatt der Bauverwaltung” 1910, Jg. 30, nr 102, s. 664. W rozprawie zamieszczono trzy zasadnicze rozdziały: Geschichtliche Grundlage, Der Bautypus, Die Einzelheiten. Ten ostatni obejmował następujące zagadnienia, ujęte w trzech podrozdziałach pierwszy, Die Wand, składał się z kilku części - Mauertechnik und Ansichtsfläche, Die Gesimse, Zinnen, Flächenschmuck, Eckprofilierungen, Die Giebel, Die Fenster, Die Portale. Kolejne podrozdziały zatytułowano Die Decke i Die Pfeiler.

Karl Weber (1870-1915) - architekt, profesor na Wydziale Architektury w gdańskiej Wyższej Szkole Technicznej w latach 1907-1913, zob. Bernhardt, Stil - Raum - Ordnung..., s. 73-76 (tam wcześniejsza literatura). 
rozprawy były 53 rysunki inwentaryzacyjne, w części sporządzone przez autora dysertacji. Pracę oceniono pozytywnie. Jeszcze w 1910 r. Fischer się habilitował, a w roku kolejnym uzyskał stanowisko docenta nieetatowego (Privatdozent).

Pierwszą wojnę światową architekt spędził w służbie wojskowej. W grudniu 1918 r. związał się ponownie z gdańską administracją budowlaną. W dniu 24 marca 1920 r. powierzono mu kierowanie utworzonym wówczas Urzędem ds. osiedli (Siedlungsamt), przemianowanym później na Urząd Rozbudowy Miasta (Stadterweiterungsamt). W tym czasie Fischer pełnił funkcję miejskiego inspektora budowalnego (Stadtbauinspektor) ${ }^{8}$. W dniu 6 września $1921 \mathrm{r}$. przejął obowiązki na terenie objętym granicami Wolnego Miasta Gdańska ${ }^{9}$ od Bernharda Schmida ${ }^{10}$, dotychczasowego konserwatora prowincjonalnego Prus Zachodnich (Provinzialkonservator von Westpreußen). W tym samym roku objął też funkcję osoby odpowiedzialnej pod względem architektonicznym za obiekty należące do kościoła ewangelicko-reformowanego (Konsistorial-Kirchenbaumeister). W kwietniu 1921 r. został mianowany wyższym radcą budowlanym (Oberbaurat) w Urzędzie Budownictwa Naziemnego. W marcu 1923 r. objął kierownictwo tego urzędu ${ }^{11}$, a w jego kompetencjach znajdowało się zarządzanie zarówno obszarem Gdańska, jak i całym terenem Wolnego Miasta.

Po zakończeniu pierwszej wojny światowej Fischer nadal współpracował z Wyższą Szkołą Techniczną. Od 1919 r. był nieetatowym profesorem (Honorarprofessor). Prowadził wykłady na temat historycznej niemieckiej architektury ceglanej okresu od średniowiecza do czasów nowożytnych oraz ćwiczenia z rysunku architektonicznego ${ }^{12}$.

W marcu 1925 r. opuścił miasto, by przenieść się do Wyższej Szkoły Technicznej w Hanowerze (Technische Hochschule Hannover), gdzie został profesorem zwyczajnym ze specjalizacją architektura średniowieczna ${ }^{13}$.

Wyjazd Fischera z Gdańska wywołał w miejscowym środowisku architektonicznym poruszenie. Zjednoczenie Gdańskich Architektów „Arche” (Danziger

8 K[urt] Fehlhaber, Danzigs Stadterweiterung, „Danziger Statistische Mitteilungen” 1926, Jg. 6, nr 11, s. 171; Wünsch, Fischer..., s. 904.

9 „Staatsanzeiger für Danzig für 1921” 1922, nr 65, s. 311.

10 Bernhard Schmid (1872-1947) - architekt, konserwator zabytków w latach 1902-1920, zob. Rainer Zacharias, Bernhard Schmid (1872-1947). Preußischer Landeskonservator und Baumeister der Marienburg [w:] Das Preußenland als Forschungsaufgabe. Eine europäische Region in ihren geschichtlichen Bezügen. Festschrift für Udo Arnold zum 60. Geburtstag gewidmet von den Mitgliedern der Historischen Kommission für ost- und westpreußische Landesforschung, Hg. Bernhart Jähnig, Georg Michels, Lüneburg 2000 (Einzelschriften der Historischen Kommission für ost- und westpreußische Landesforschung, Bd. 20), s. 689-714.

11 Wünsch, Fischer..., s. 904.

12 Bernhardt, Stil - Raum - Ordnung..., s. 85, 88.

13 Katja Bernhardt wspomina o obietnicy Senatu WMG, żeby zatrudnić Fischera jako profesora zwyczajnego, jednak ostatecznie władze wycofały się z niej, zob. Bernhardt, Stil - Raum - Ordnung..., s. 89.
Działalność architekta Friedricha Fischera... 
Ewa Architektenvereinigung „Die Arche”), doceniając jego zasługi, zwróciło się Barylewska- do władz Senatu o zatrzymanie Fischera w Gdańsku ${ }^{14}$. Ale decyzja była nie-Szymańska odwracalna, architekt przyjął już nowe stanowisko spełniające jego naukowe ambicje i nie zamierzał z niego zrezygnować. $Z$ hanowerską Wyższą Szkołą Techniczną pozostał związany aż do śmierci - do 19 czerwca 1944 r. W okresie hanowerskim był nadal czynnym architektem.

Przegląd dokonań Fischera rozpoczniemy się od jego prywatnej działalności architektonicznej. W $1911 \mathrm{r}$. odszedł ze służby państwowej i otworzył biuro architektoniczne, które mieściło się przy ul. Ogarnej (Hundegasse) $62^{15}$.

We Wrzeszczu przy ul. Uphagena (Uphagenweg), na rozparcelowanym terenie dawnej podmiejskiej posiadłości gdańskiego patrycjusza Johanna Uphagena, architekt zaprojektował kilka domów. Na parceli oznaczonej numerem 16 powstała w 1914 r. willa dla kupca Fritza Bartscha (il. 1). Fischer był autorem projektu i nadzorował prace budowlane. Program użytkowy domu był dostosowany do potrzeb zasobnego gdańszczanina. W piwnicy usytuowano kotłownię, skład węgla i pralnię. Wydzielono tu również mieszkanie dla dozorcy, składające się z dwóch pokoi, kuchni i ubikacji, jednak w pierwszym etapie odstąpiono od wykańczania tych wnętrz. Na parterze umieszczono jadalnię, pokój muzyczny i gabinet pana domu. Znalazła się tu również kuchnia. Piętro mieściło sypialnię gospodarzy, pokój dziecięcy, dwa pokoje gościnne i służbówkę. $\mathrm{Na}$ poddaszu usytuowano suszarnię.

Jasne, tynkowane elewacje budynku, artykułowane lizenami, pozbawione są niemal detalu, oś środkową elewacji frontowej akcentuje na parterze ozdobnie opracowane okno. Od strony ogrodu usytuowano werandę i schody do ogrodu. Wejście do budynku umieszczono w elewacji bocznej, nad nim znajduje się balkon. Dom został nakryty wysokim czterospadowym dachem. Na jednej $\mathrm{z}$ elewacji architekt zaprojektował kratkę na pnącze ${ }^{16}$. Projekt stanowi czytelne odwołanie do niemieckiej architektury reformy (Reformarchitektur), a w jej ramach do nurtu „około $1800 ” 17$.

14 Berufungen, „Deutsche Bauzeitung” 1925, Jg. 59, nr 14, s. 110.

15 Na pieczątce Fischera, znanej z projektów, widnieje adres biura, zob. Archiwum Państwowe w Gdańsku, Państwowy Urząd Policji Budowlanej w Gdańsku, sygn. akt 15/2447, Uphagenweg 16, b.p.

16 Archiwum Państwowe w Gdańsku, Państwowy Urząd Policji Budowlanej w Gdańsku, sygn. akt 15/2447, Uphagenweg 16, passim.

17 Propagatorem nurtu był architekt Paul Mebes (1872-1938), zob. Paul Mebes, Um 1800. Architektur und Handwerk im letzten Jahrhundert ihrer traditionellen Entwicklung, Bd. 1-2, München 1908. Na temat różnych nurtów architektury reformy zob. m.in. Sigrid Hofer, Reformarchitektr 1900-1918. Deutsche Baukünstler auf der Suche nach dem nationalen Stil, Stuttgart-London 2005, passim. Na temat recepcji weimarskiego domu ogrodowego Goethego jako bardzo ważnego punktu odniesienia dla architektów nurtu reformy, zob. Wolfgang Voigt, Vom Ur-Haus zum Typ. Paul Schmitthenners, deutsches Wohnhaus' und seine Vorbilder [w:] Moderne Architektur in Deutschland 1900 bis 1950. Reform und Tradition, Hg. Vittorio Magnago Lampugnani, Romana Schneider, Stuttgart [1992], s. 245-247. Przy omawianiu zjawisk architektonicznych początku XX w. Rafał Makała stosuje polskojęzyczny termin architektura reformy, ukazując wielowątkowość nurtu, zob. 


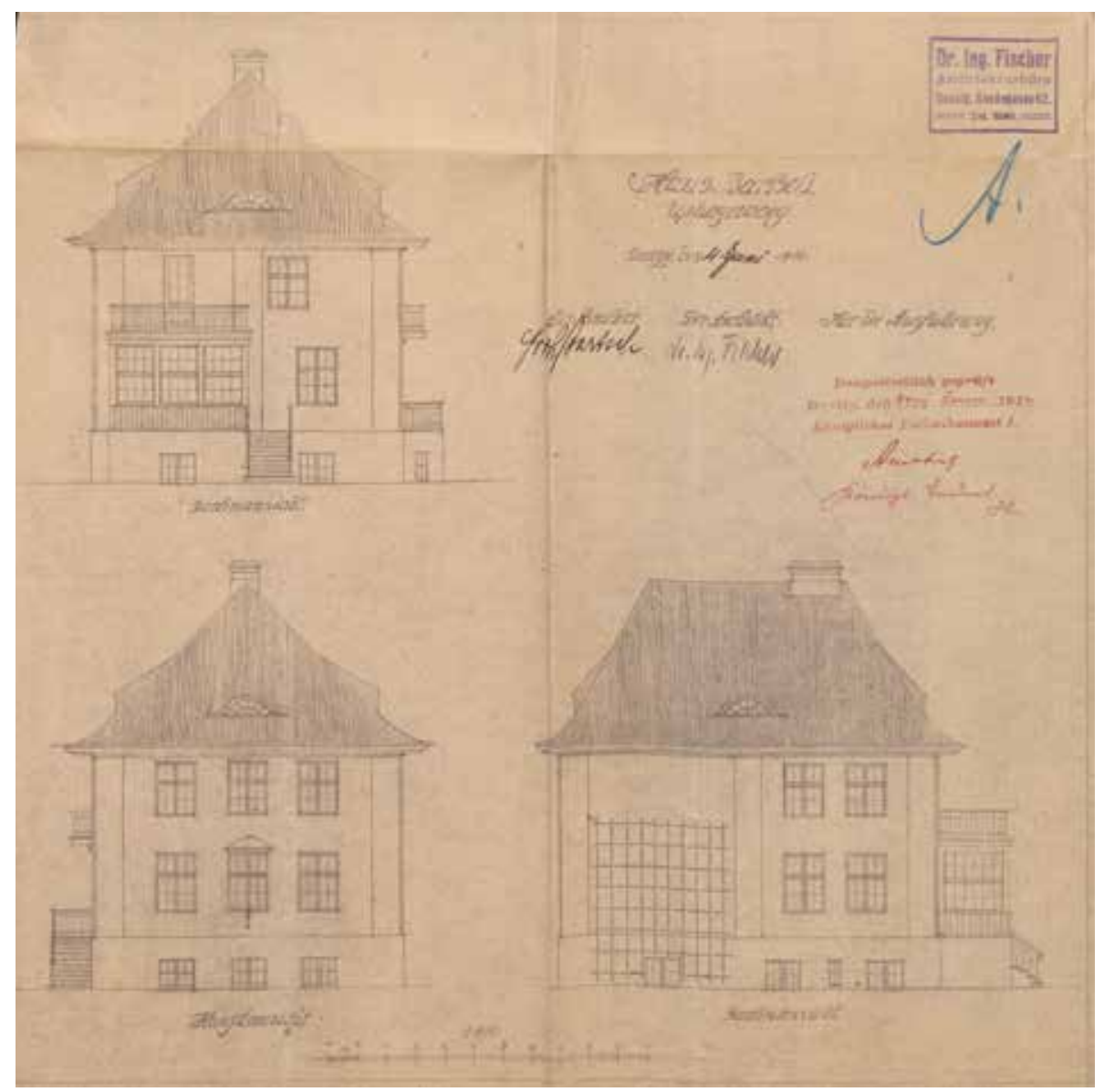

Działalność architekta Friedricha Fischera...

Il. 1. Projekt willi dla kupca Fritza Bartscha przy ul. Uphagena 16 w Gdańsku Wrzeszczu, fasada i dwie elewacje boczne, Archiwum Państwowe w Gdańsku, sygn. 15/2447

Fischer był też autorem projektu kilku innych domów przy tej samej ulicy. Na stosunkowo wąskich posesjach, o szerokości 9 metrów, położonych wzdłuż torów kolejowych, powstały domy szeregowe. Wśród właścicieli byli dwaj znani gdańszczanie. Jednym z nich był Fritz Pfuhle, malarz, grafik i profesor rysunku oraz akwareli w Wyższej Szkoły Technicznej, który od 1910 r. aż do drugiej wojny światowej mieszkał i tworzył w Gdańsku ${ }^{18}$. Drugim inwestorem był sam Fischer, należał do niego dom $\mathrm{nr} 25^{19}$. Właścicielami kolejnych domów byli

Rafał Makała, Nawiązania do tradycji nowożytnej w ceglanej architekturze wczesnomodernistycznej pótnocnych Niemiec, „Porta Aurea” 2018, t. 17, s. 94-95, 97-98.

18 Bernhardt, Stil - Raum - Ordnung..., s. 84-85.

19 Właścicielem nieruchomości był zapewne krótko, bo już w 1918 r. jest poddawany inny właściciel domu, prof. Hans von Wartenberg z Wyższej Szkoły Technicznej, zob. Neues Adreßbuch für Danzig und Vororte 1918, Teil. 3 [Danzig 1928], s. 249. 
Ewa wdowa po lekarzu Müllerze i kupiec Lanser. Cztery domy wzniesiono zapewne Barylewska-Szymańska w 1914 r., tak datowany jest segment należący do Lansera ${ }^{20}$ (il. 2). Pomimo niewielkiej powierzchni działek domy miały sporą liczbę pokoi oraz pełne zaplecze gospodarcze. W piwnicach umieszczono pralnię oraz kotłownię i skład opału. Parter mieścił od strony ogrodu jadalnię, a od frontu pokój dzienny. W niewielkim aneksie na tyłach domu znajdowały się kuchnia i mała spiżarnia. Na piętrze mieściły się trzy sypialnie oraz toaleta i łazienka (w aneksie), ta ostatnia - dość nietypowo - z wyjściem na balkon. Poddasze miało użytkowy charakter, znajdowały się tam trzy niewielkie pokoje i komora (w aneksie).

Domy wyróżniały się na tle willowej zabudowy ulicy. Każdy z segmentów miał inny szczyt wieńczący wystawkę usytuowaną na osi fasady. Nawiązywały one do schodkowych średniowiecznych szczytów gdańskich kamienic. Odwołaniem do tradycyjnej gdańskiej architektury były także ceglane elewacje. Architekt w późniejszych projektach powracał do ceglanej architektury, interpretowanej jako odwołanie do tradycji gdańskiej i północnoniemieckiej, którą zajmował się też naukowo ${ }^{21}$. Widoczne są także wpływy architektury angielskiej ${ }^{22}$.

Kolejna gdańska realizacja Fischera to dom dla Kurta Siebenfreuda ${ }^{23}$, współwłaściciela firmy wydawniczej „W.F. Burau”, a następnie współwłaściciela „Danziger Verlags-Gesellschaft m.b.H.”, polityka i znanego społecznika, m.in. przewodniczącego Stowarzyszenia Przyjaciół Sztuki (Kunstverein). Budynek wzniesiono przy Wielkiej Alei (Große Allee) 55, obecnie al. Zwycięstwa (Trakt Konny), nieopodal dawnej Bramy Oliwskiej, na dużej narożnej działce. Obiekt zbudowano zapewne na początku lat dwudziestych XX w., a w księdze

20 Archiwum Państwowe w Gdańsku, Państwowy Urząd Policji Budowlanej w Gdańsku, sygn. akt 15/2450, Uphagenweg 27, passim. Akta nie zachowały się dla sąsiednich domów, w tym dla domu Fischera. W późniejszym okresie po obu stronach szeregu czterech domów wzniesiono dwa kolejne; dla tych obiektów także brakuje akt.

${ }_{21}$ Zob. przyp. 5. Uwieńczeniem badań nad tą tematyką była wydana w 1944 r. publikacja jego autorstwa Norddeutscher Ziegelbau.

22 W ramach architektury reformy można wskazać na oddziaływanie Hermanna Muthesiusa (1861-1927), wpływ wywarła zwłaszcza jego publikacja - Das englische Haus, Bd. 1-3, Berlin 1903-1904, w której omówił on m.in. angielskie obiekty historyczne i współczesne realizacje - rezydencje, domy podmiejskie, domy robotnicze. Artykuł poświęcony tej tematyce zob. idem, Das Fabrikdorf Port Sunlight bei Liverpool, „Zentralblatt der Bauverwaltung” 1899, Jg. 19, s. 133-136, 146-148. Julius Posener podkreślał znaczenie wzorców angielskich i roli, jaką odegrał sam Muthesius dla architektury reformy, zob. Julius Posener, Berlin aufdem Wege zu einer neuen Architektur. Das Zeitalter Wilhelms II., München-New York 1995, s. 17-20, 127-151. Zob. też Andrzej Szczerski, Wzorce tożsamości. Recepcja sztuki brytyjskiej w Europie Środkowej około roku 1900, Kraków 2002 (Ars vetus et nova, t. 10, red. Wojciech Bałus), s. 136-137; Regina Stephan, Hermann Muthesius' Studien in England und „Das englische Haus” 1904 [w:] 100 Jahre Deutscher Werkbund 1907/2007, Hg. Winfried Nerdinger, München 2007, s. 23-24; Axel Schollmeier, Gartenstädte in Deutschland. Ihre Geschichte, städtebauliche Entwicklung und Architektur zu Beginn des 20. Jahrhunderts, Münster 1990, s. 50.

23 Herrmann Schmitz, Die Bautätigkeit Fischers im Freistaate Danzig, „Zeitschrift für bildende Kunst" 1924/1925, Jg. 58, H. 7, s. 137. 


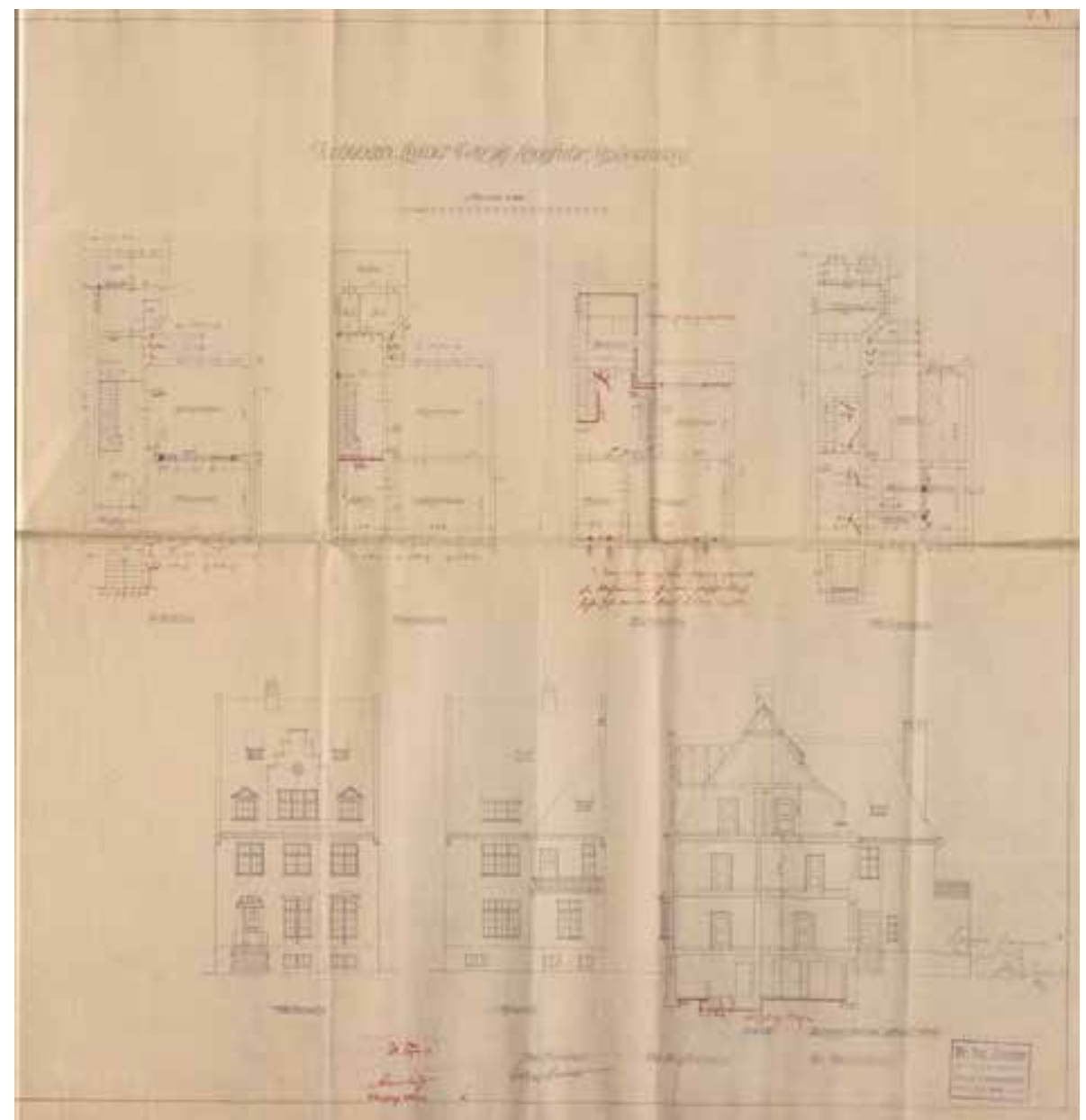

Działalność architekta Friedricha Fischera...

Il. 2. Projekt domu szeregowego dla kupca Lansera przy ul. Uphagena w Gdańsku Wrzeszczu, fasada, elewacja tylna, przekrój i rzuty kondygnacji, Archiwum Państwowe w Gdańsku $15 / 2450$

adresowej Siebenfreuda odnotowano pod tym adresem w 1924 r..$^{24}$ Dwukondygnacyjny, czteroosiowy dom, usytuowany kalenicą wzdłuż Wielkiej Alei, został nakryty wysokim dwuspadowym dachem z wystawką od strony fasady. Szczyty elewacji bocznych ukształtowano w typowy dla Fischera sposób, od ul. Chodowieckiego dodatkowo z kulą i kutą chorągiewką. Na osi fasady umieszczono główne wejście do budynku, boczne znalazło się w szczycie domu. Dom położony jest $\mathrm{w}$ dużym ogrodzie.

24 Adressbuch für Danzig 1924, Teil. 2, s. 69 (w księdze adresowej za 1921 r. jeszcze nie występuje). 

dom letni, który powstał na zamówienie dr Franka Muscate, skoligaconego z Fischerem (il. 3). Budynek, położony malowniczo na szczycie wzgórza, umożliwiał rozległy widok na Zatokę Gdańską. Fasada, z rzadko u Fischera stosowanymi kolumnami ujmującymi wejście domu, nawiązuje do podmiejskich siedzib gdańskich z okresu około $1800 \mathrm{r}$. Interesująco rozwiązana została elewacja ogrodowa $\mathrm{z}$ dwoma ukośnie usytuowanymi aneksami, mieszczącymi ośmioboczne pokoje, oświetlone oknami skierowanymi na trzy strony. Dom został przekryty wysokim dachem ${ }^{25}$. Pomiędzy aneksami usytuowano taras.

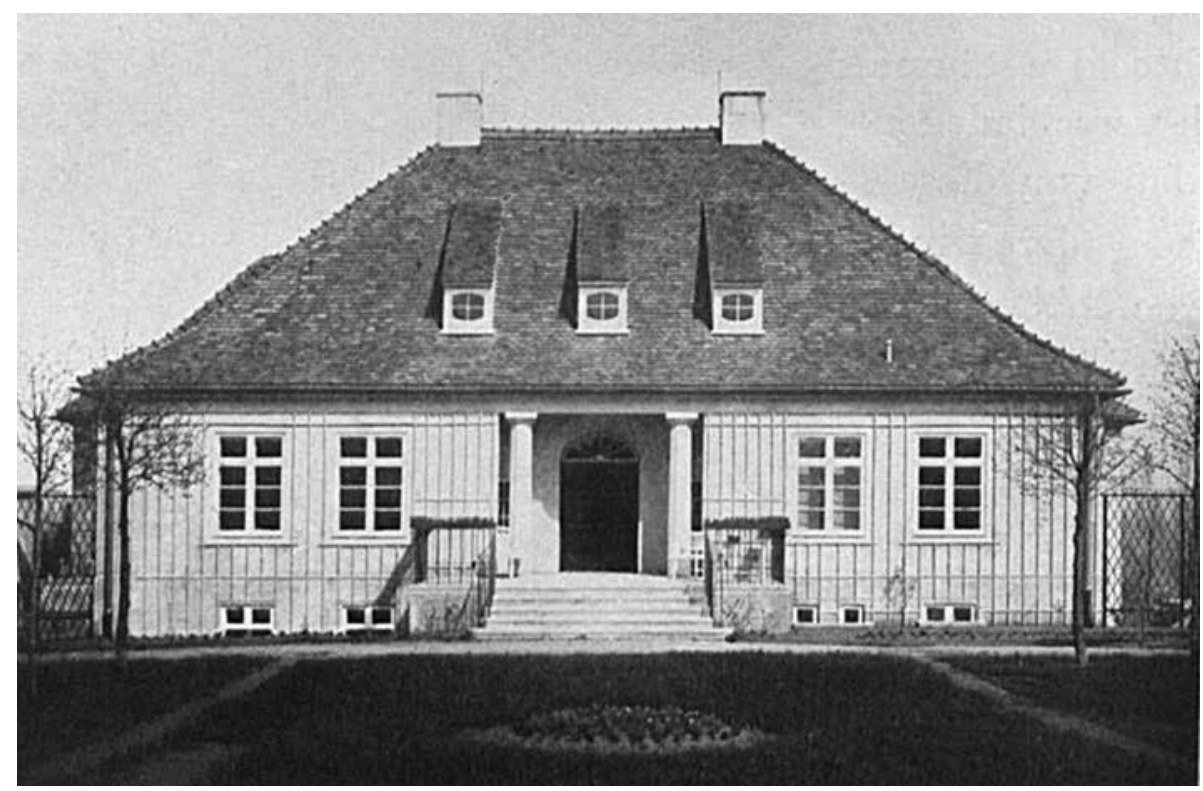

Il. 3. Willa dr Franka Muscate przy ul. Sępiej 18 w Sopocie, repr. za: Herrmann Schmitz, Die Bautätigkeit Fischers im Freistaate Danzig, „Zeitschrift für bildende Kunst” 1924/1925, Jg. 58, H. 7

Przy obecnej ul. Stefana Żeromskiego (Sternweg) 30 Fischer zbudował własny $\mathrm{dom}^{26}$. Wspaniale usytuowany, $\mathrm{z}$ rozległym widokiem na zatokę i okoliczne lasy, w otoczeniu dużego, zróżnicowanego wysokościowo ogrodu, w którym ukształtowano tarasy i wkomponowano małą architekturę (np. pergole). Posesję ogrodzono prostym drewnianym płotem. Oszczędna, tynkowana bryła dwukondygnacyjnego budynku była pozbawiona detalu, jedyny akcent kolorystyczny stanowiły okiennice zamontowane na parterze i barwna stolarka okienna. Dom nakryto wysokim

25 Obiekt został przebudowany z zatarciem pierwotnej wizji architektonicznej, aneksy są zachowane.

26 Schmitz, Die Bautätigkeit Fischers..., s. 136-137. Za pomoc w ustaleniu danych dotyczących sopockich realizacji Fischera i właścicieli willi przy ul. Sępiej jestem zobowiązana dr Januszowi Dargaczowi z Muzeum Gdańska, a wcześniej z Muzeum Sopotu. 
dwuspadowym dachem, kryjącym użytkowe poddasze, doświetlone w elewacjach szczytowych dużymi oknami. Do ogrodu prowadziły dwubiegowe schody z prostą metalową balustradą, nad wejściem umieszczono zadaszenie wsparte na dwóch prostych podporach. Zastosowany w elewacjach bocznych typ szczytu był wykorzystywany także w innych projektach architekta (il. 4). Po wyjeździe Fischera z Gdańska dom pozostał własnością jego żony Ruth ${ }^{27}$.

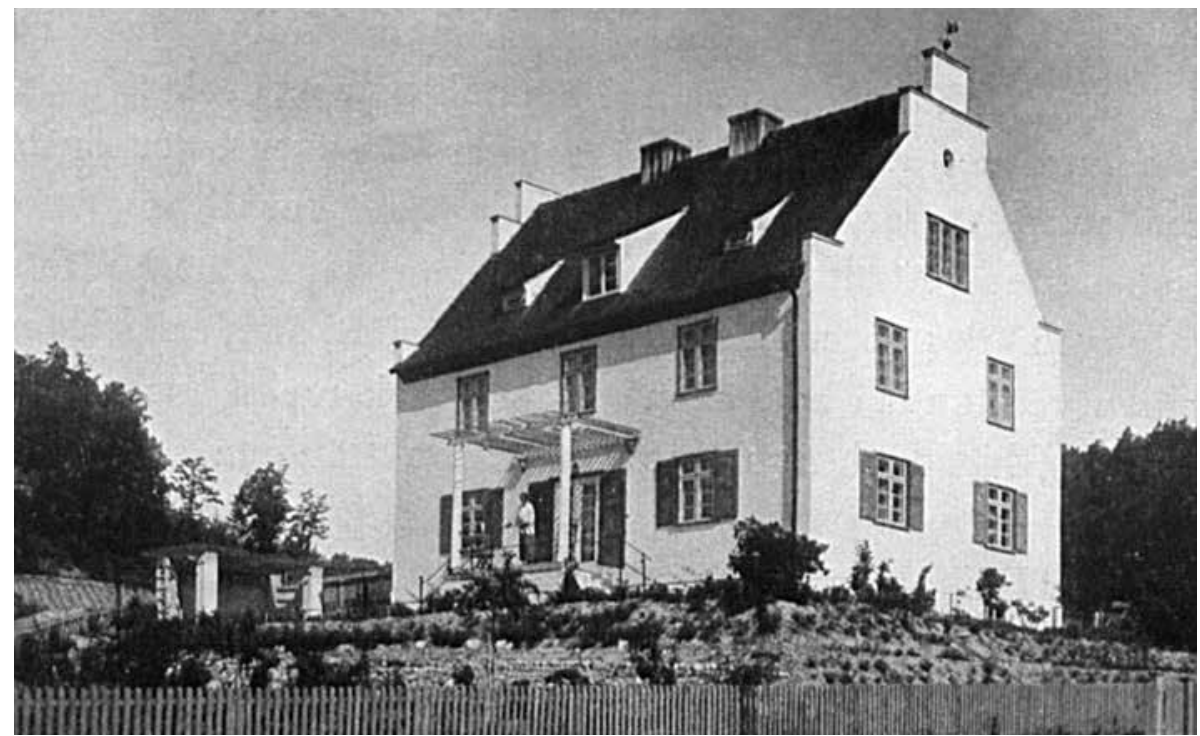

Il. 4. Dom Friedricha Fischera przy ul. Stefana Żeromskiego 30 w Sopocie, repr. za: Herrmann Schmitz, Die Bautätigkeit Fischers im Freistaate Danzig, „Zeitschrift für bildende Kunst” 1924/1925, Jg. 58, H. 7

Kolejnym polem aktywności architekta była działalność planistyczna. Fischer jako urbanista przygotowywał projekty w ramach kierowanego przez niego urzędu. Panujący w wielu miastach po zakończeniu pierwszej wojny światowej głód mieszkaniowy wymusił na zarządach miejskich tworzenie wyspecjalizowanych urzędów zajmujących się planowym rozwojem ${ }^{28}$, gdański urząd nie był tu odosobniony. Po wojnie nowe podejście do miasta jako całości, uwzględniające w znaczniejszym stopniu aspekty zdrowotne, sprawiło, że w miejsce wcześniejszych cząstkowych planów, utrudniających prawidłowy rozwój miasta, prowadzono prace nad planami ogólnymi, na tym tle gdańskie plany są również typowym działaniem ${ }^{29}$.

27 Zob. Adreßbuch Zoppot 1929..., s. 92. Za zwrócenie mi uwagi na ten zapis dziękuję dr Januszowi Dargaczowi.

28 Na ten temat zob. np. Wolfgang Pehnt, Deutsche Architektur seit 1900, München 2005, s. 91-93.

29 Całościowe myślenie o mieście znalazło swoje wczesne odzwierciedlenie w warunkach konkursu na plan urbanistyczny „Wielkiego Berlina” z 1910 r., obejmującego swym zasięgiem duży obszar podmiejski. Julius Posener zauważył: „Man versuchte, die Berliner Stadtregion zu planen. 
W kompetencjach gdańskiego urzędu zajmującego się tymi kwestiami Barylewska-Szymańska mieściło się wiele zadań, Fischer kierował sporządzaniem pomiarów oraz planów urbanistycznych, podlegały mu również zadania związane z komunikacją (planowanie nowych dróg) czy też przygotowanie terenów przeznaczonych na ogrody działkowe. Powstawały tu także plany nowych osiedli, a nawet załatwiano kwestie finansowe niezbędne do realizacji tego typu zadań ${ }^{30}$.

W tym czasie rozpoczęły się prace nad planem Wielkiego Gdańska, znanym jako „plan [Hugo] Althoffa”"31. Podstawowym zadaniem stało się na początku prac - jak to ujął Kurt Fehlhaber, następca Fischera na stanowisku kierownika tego urzędu - wytyczenie kierunków rozwoju na kolejne generacje i na tej podstawie sporządzenie planów cząstkowych, zgodnych z aktualnymi potrzebami ${ }^{32}$. Do 1924 r. opracowano ogólny plan rozwoju (Generalbebaungsplan), w którym podzielono obszar miasta na tereny mieszkaniowe i przemysłowe, zaplanowano również rozwój portu, drogi wodne, wreszcie komunikację tranzytową i lokalną. Zasadnicze znaczenie miało tworzenie obszarów zielonych, których w mieście brakowało ${ }^{33}$. W tym czasie powstał także plan obejmujący fragment Wrzeszcza, dla tej części miasta ulicę obwodową stanowiła obecna ul. Kościuszki (Ringstraße), a wokół planowano zabudowę mieszkaniową, wzniesienie obiektów sportowych oraz budynków użyteczności publicznej ${ }^{34}$. Nad tymi właśnie zadaniami w początkowym okresie czuwał Fischer.

Innym zadaniem architekta $w$ ramach urzędu, choć zbieżnym z planem Wielkiego Gdańska, było opracowanie planów obszarów zielonych usytuowanych na dawnych terenach fortecznych. Założono pozostawienie fortyfikacji i stworzenie na ich koronie promenad, placów zabaw dla dzieci i miejsc rekreacji. W tym czasie nie było to oczywiste, było wielu zwolenników splantowania tych

Keine andere europäische Großstadt hat sich so früh mit diesen Themen beschäftigt", zob. Posener, Berlin auf dem Wege..., s. 11). Całościowo projektowano w tym czasie nowo zakładane miasta-ogrody, zob. Thomas Krückemeyer, Gartenstadt als Reformmodell. Siedlungskonzeption zwischen Utopie und Wirklichkeit, Siegen 1997, s. 58-73.

30 Fehlhaber, Danzigs Stadterweiterung..., s. 170.

31 Hugo Althoff (1884-1960) - w okresie od grudnia 1929 do maja 1933 r. senator, któremu podlegały m.in. kwestie budowlane. Przystępując do prac nad planem Wielkiego Gdańska, stwierdził: „Eine Reihe wertvoller Vorarbeiten von meinen Vorgängern liegt hierfür vor”. Na temat planu Althoffa zob. m.in. Katarzyna Rozmarynowska, $Z$ działalności i twórczości architekta Hugona Althoffa - senatora Wolnego Miasta Gdańska w latach 1928-1933 [w:] 100-lecie nowoczesnej urbanistyki w Gdańsku, red. Małgorzata Postawka, Piotr Lorens, Gdańsk 2009, s. 66-68; Piotr Lorens, Rozwój urbanistyczny Gdańska w latach 1918-1945 [w:] 100-lecie nowoczesnej urbanistyki..., s. 80-85.

32 Fehlhaber, Danzigs Stadterweiterung..., s. 170.

33 Bericht über die Verwaltung der Stadtgemeinde Danzig vom 1. April 1920 bis 31. März 1925, Hg. Statistisches Landesamt der Freien Stadt Danzig, Danzig 1926, s. 127; Fehlhaber, Danzigs Stadterweiterung..., s. 171-173.

34 Plan został opublikowany przez Althoffa, zob. [Hugo] Althoff, Danzig [w:] Städtebau und Wohnungswesen der Welt. Town planning and housing throughout the world. L'urbanisme et l'habitation dans tous les pays, Hg. Bruno Schwan, Berlin 1935, s. 145. 
terenów i wypełnienia ich zabudową, jak to uczyniono na przełomie wieków $\mathrm{z}$ frontem zachodnim ${ }^{35}$. Pierwsza promenada o długości $6400 \mathrm{~m}$ powstała w latach 1920-1922, zlokalizowano ją na terenie Biskupiej Górki ${ }^{36}$. Fischer był też autorem wytyczenia i rozplanowania dzisiejszej al. Hallera (Ostseestraße) $\mathrm{w}$ formie szerokiej, obsadzonej drzewami alei z promenadą. Miała ona w założeniu nawiązywać do Wielkiej Alei komunikującej Gdańsk i Wrzeszcz ${ }^{37}$.

Fischer uczestniczył też zapewne w przygotowaniu projektu urbanistycznego (prawdopodobnie wstępnego) Cmentarza Centralnego (Zentralfriedhof) w Srebrnikach ${ }^{38}$. W 1925 r., już po jego wyjeździe z Gdańska, rozpoczęto na tym terenie pierwsze prace ziemne $e^{39}$.

Przejdźmy do projektów architektonicznych. W 1920 r. architekt uczestniczył w konkursie na gdański wysokościowiec ${ }^{40}$. Wspólnie z Albertem Krügerem, pracownikiem urzędu, przygotował projekt, który nie spełnił jednak wymogów określonych w warunkach konkursu i został odrzucony. Jury orzekło, że autorzy zdecydowali się na mniejszą niż wymagana liczbę kondygnacji, ponieważ uznali za niewłaściwe ingerowanie w krajobraz miasta jako jednorodnego zespołu urbanistycznego. Nie chcieli także, by nowy gmach wpływał negatywnie na pobliski kościół św. Trójcy. Projekt zakładał wzniesienie budynku głównego oraz dwóch trójkondygnacyjnych skrzydeł bocznych imitujących ustawione szczytowo kamienice z podcieniami w przyziemiu (il. 5). Rozległy plac z fontanną był obszarem integrującym oba zespoły urbanistyczne. Architekci zaproponowali nietypowe rozwiązanie - komunikacja pomiędzy ul. Rzeźnicką (Fleischergasse) a Zaroślakiem miała się odbywać wewnątrz budynku głównego.

35 Zob. Małgorzata Omilanowska, Defortyfikacja Gdańska na tle przekształceń miast niemieckich w XIX wieku [w:] Budowanie nad Bałtykiem. Studia z architektury i sztuki Gdańska, Pomorza i Żmudzi, Gdańsk 2018, s. 8-41.

36 Bericht über die Verwaltung..., s. 127; Danzigs Grüngürtel, „Danziger Zeitung” 1920, Jg. 63 , nr 237, 3. Blatt z 23 maja. Przytaczane w tym tekście artykuły prasowe zawdzięczam kwerendzie przeprowadzonej przez Wojciecha Szymańskiego, w tym miejscu bardzo dziękuję za pomoc.

37 Otto Kloeppel, Die Ostseestraße der Zukunft, „Danziger Neueste Nachrichten” 1925, Jg. 32, nr 114, 1. Beilage z 16 maja.

38 W sprawozdaniu za lata 1920-1925 nie sprecyzowano, kiedy dokładnie powstał projekt. Wspomniano jedynie, że zadanie powierzono Urzędowi Rozbudowy Miasta. Przyjmuje się, że nastąpiło to w 1925 r., por. Bericht über die Verwaltung..., s. 127. Z kolei w jednej z biografii Fischera projekt cmentarza powiązano z jego osobą i datowany jest on już na 1921 r., por. Lindau, Fischer..., s. 333.

39 Opracowane na podstawie noty Cmentarz Centralny autorstwa Wojciecha Szymańskiego, przeznaczonej do Atlasu architektury Gdańska (w przygotowaniu).

40 Ewa Barylewska-Szymańska, Wojciech Szymański, Konkurs na gdański wieżowiec w 1920 roku [w:] Architektura modernistyczna budynków użyteczności publicznej, Zakład Historii Architektury i Konserwacji Zabytków. Wydział Architektury Politechniki Gdańskiej. Materiały posesyjne. Gdańsk 2004, s. 81-84; eidem, Gdański drapacz chmur, „30 dni” 2007, nr 6 (74), s. 26-34. Na temat "gorączki wieżowców” zob. Beate Störtkuhl, Wieżowce we Wrocławiu a „gorączka wysokościowców" w Niemczech lat dwudziestych [w:] Wieżowce Wrocławia, red. Jerzy Ilkosz, Beate Störtkuhl, Wrocław 1997, s. 13-25. 


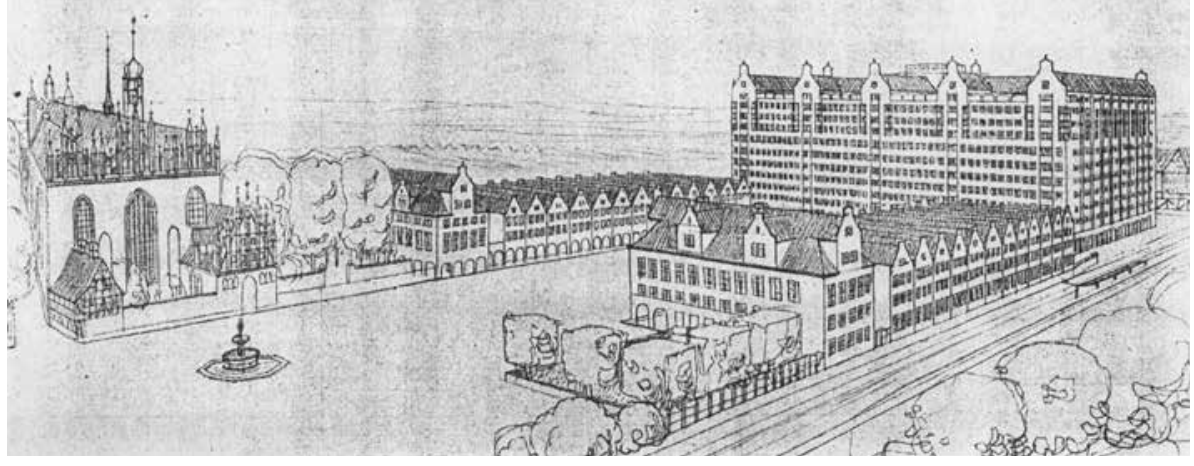

Il. 5. Projekt zgłoszony w konkursie na gdański wieżowiec autorstwa Friedricha Fischera i Alberta Krügera, 1920, repr. za: „Der Baumeister” 1924, Jg. 19, H. 4.

Fischer przygotował także inny projekt (nie jest jasne, czy został on zgłoszony w konkursie, czy też powstał już po jego zakończeniu), który opublikowano $w$ gazecie codziennej ${ }^{41}$. Tym razem architekt zdecydował się na siedemnastokondygnacyjny wieżowiec (il. 6), przekryty płaskim dachem, z ośmioma skrzydłami usytuowanymi wokół centralnego dziedzińca. W tej części znajdować się miały windy, schody oraz zaplecze sanitarne. Niektóre restauracje architekt planował umieścić na najwyższej kondygnacji, inne na pierwszym piętrze. Interesująca była propozycja urządzenia ogrodu na dachu wieżowca, co stanowiło bezpośrednie odwołanie do amerykańskich wysokościowców. To właśnie to rozwiązanie, przedstawione w artykule prasowym, wzbudziło największe zainteresowanie. Fischer nawiązał też do poprzedniego projektu - zamknął plac przed wieżowcem dwoma długimi trzykondygnacyjnymi skrzydłami, nakrytymi dwuspadowymi dachami, zakończonymi wyniesioną partią ukształtowaną w nawiązaniu do fasad kamienic. Wszystkie projekty pozostały na papierze, a sen o metropolitalnym Gdańsku z imponującym wieżowcem nie ziścił się.

Fischer odniósł się też w artykule prasowym do tematyki wieżowca. Wskazywał, że wysokościowiec powinien powstać w innym miejscu, jednak gdańszczanie nie są jeszcze gotowi na pokonywanie większych odległości, dlatego wybrana lokalizacja jest korzystna. Zaznaczył również, że bez stworzenia odpowiedniej liczby miejsc handlu i biur nie można zachować historycznej struktury miasta. Pokusa przekształceń i przebudów, by dostosować lokale do współczesnych wymogów, będzie zbyt duża.

Kolejne prace projektowe są związane z urzędową działalnością Fischera. Jednym z pierwszych projektów było osiedle przy dzisiejszej ul. Zbyszka z Bogdańca

${ }_{41}$ [Friedrich] Fischer, Danzigs Kulturgüter. Bemerkungen zum Thema „Bürohaus und Maifestspiele”, „Danziger Zeitung” 1922, Jg. 65, nr 283, Morgenausgabe z 20 czerwca. 


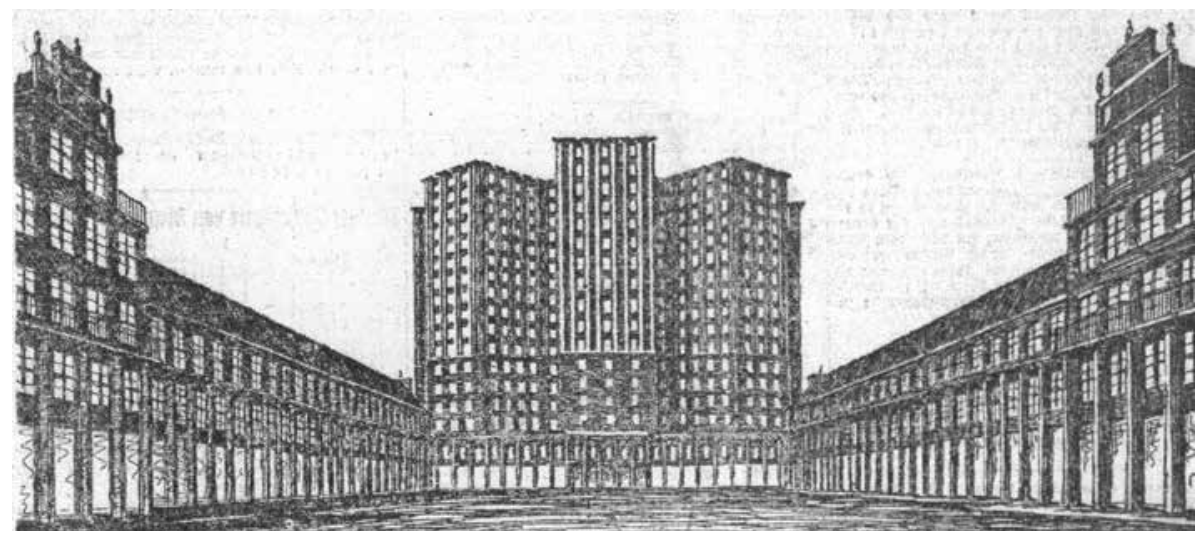

Działalność

architekta

Friedricha

Fischera...

Il. 6. Projekt wieżowca autorstwa Friedricha Fischera, repr. za: Friedrich Fischer, Danzigs

Kulturgüter. Bemerkungen zum Thema „Bürohaus und Maifestspiele”, „Danziger Zeitung” 1922, Jg. 65, nr 283, Morgenausgabe z 20 czerwca

(Westerzeile) oraz ul. Duboisa (Osterzeile) ${ }^{42}$. Plan osiedla przygotowano w latach 1920-1921. Bezpośrednio po zatwierdzeniu projektów przystąpiono do prac budowlanych. A około 1924 r. domy były już zasiedlane ${ }^{43}$. Powstała zabudowa szeregowa (il. 7), z położonymi na zapleczu ogrodami o sporej powierzchni. Fischer był zwolennikiem budownictwa jednorodzinnego, $\mathrm{z}$ domami usytuowanym w dużych ogrodach. Uważał, że tego rodzaju miejsce zamieszkania sprzyja związkom z „małą ojczyzną", uczy patriotyzmu ${ }^{44}$. Był propagatorem idei zakładania osiedli domów jednorodzinnych, które pozwolą na realizację tego celu, takie widział też zadania dla nowo powołanego urzędu. Fischer miał świadomość, że budownictwo wielorodzinne w centrum miasta jest konieczne, jednak na odleglejszych obszarach

42 Na temat inicjatyw państwowych na terenie Niemiec po 1918 r. [!] zob. Dorothea Berger-Thimme, Wohnungsfrage und Sozialstaat. Untersuchungen zu den Anfängen staatlicher Wohnungspolitik in Deutschland (1873-1918), Frankfurt am Main 1976, s. 263-281.

43 Fischer współpracował $\mathrm{z}$ architektem Kurtem Fehlhaberem. Opracowano na podstawie noty Osiedle przy Zbyszka z Bogdańca i Duboisa autorstwa Wojciecha Szymańskiego, przeznaczonej do Atlasu architektury Gdańska (w przygotowaniu). Osiedle zostało wymienione w ramach dużej struktury urbanistycznej jako „osiedle Kościuszki” w publikacji Romany Cielątkowskiej i Piotra Lorensa, Architektura i urbanistyka osiedli socjalnych Gdańska okresu XX-lecia międzywojennego, Gdańsk 2000, s. 147-148, 150.

44 „Wer [...] ohne Beziehung zu Garten und Natur aufgewachsen ist, der kann kein Heimatgefühl haben”. Jego poglądy wpisywały się w propagowane już na początku XX w. na terenie Niemiec reformatorskie idee obejmujące poprawę warunków życia (Lebensreform). Idee te zakładały polepszenie sytuacji mieszkaniowej, zawłaszcza niższych warstw społecznych. Wśród reformatorów architektury można wskazać zarówno przywoływanego wcześniej Muthesiusa, jak i Paula Schultze-Naumburga, ale krąg ten obejmuje wiele innych osobistości będących członkami Werkbundu czy też Niemieckiego Towarzystwa Miast-Ogrodów (Deutsche Gartenstadtgesellschaft), popierających też założenie budownictwa spółdzielczego i towarzystw budowlanych, zob. np. Norbert Borrmann, Paul Schultze-Naumburg. 1869-1949. Maler, Publizist, Architekt. Vom Kulturreformer der Jahrhundertwende zum Kulturpolitiker im dritten Reich, Essen 1989, s. 25-140. 


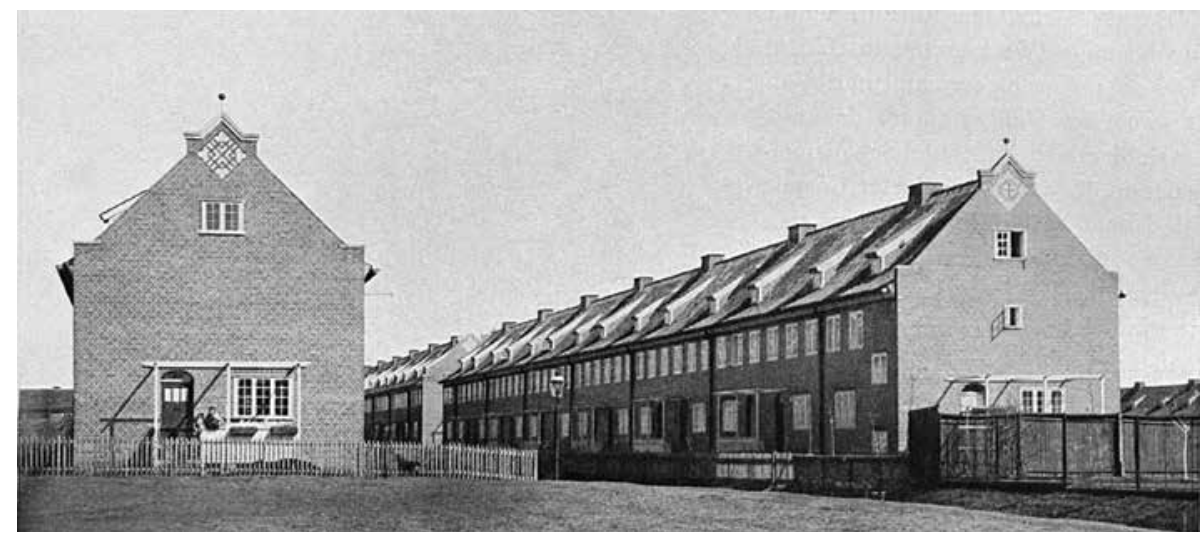

Il. 7. Zabudowa szeregowa przy ul. Zbyszka z Bogdańca w Gdańsku Wrzeszczu, repr. za: Herrmann Schmitz, Die Bautätigkeit Fischers im Freistaate Danzig, „Zeitschrift für bildende Kunst” 1924/1925, Jg. 58, H. 7

należy budować domy w ogrodach. Uznawał to również za bardziej korzystne rozwiązanie z ekonomicznego punktu widzenia ${ }^{45}$.

Ceglane elewacje domów były pozbawione artykulacji, jedynie w szczytach elewacji bocznych umieszczono opracowany ozdobnie element dekoracyjny, zróżnicowany dla każdego z szeregu domów. Do budynków przy ul. Zbyszka z Bogdańca wejście wiodło poprzez drewniany ganek, nad drzwiami znajdowało się proste drewniane zadaszenie.

Program funkcjonalny obejmował umieszczoną w suterenie pralnię i pomieszczenia piwniczne, na parterze mieściła się kuchnia i pokój, na kolejnej kondygnacji znajdowały się trzy pokoje i ubikacja, a na poddaszu można było wydzielić dwa kolejne małe wnętrza mieszkalne. W projektach nie przewidziano łazienki, jednak w piwnicy było dostatecznie dużo miejsca, żeby takie pomieszczenie umieścić. Domy były podłączone do wodociągów i kanalizacji, co nie było regułą we wczesnym etapie budownictwa mieszkaniowego w Wolnym Mieście Gdańsku.

W innym miejscu Wrzeszcza planowano budowę nowego fragmentu dzielnicy - obejmował on obszar pomiędzy obecnymi ulicami Kościuszki (Ringstraße), Lelewela (Labensweg) i Legionów (Heeresanger). Na tym terenie powstał nowy plac, dzisiejszy pl. Wybickiego (Neuer Markt). Po jego obu stronach przewidziano niewielkie domy wielorodzinne. Następca Fischera na stanowisku szefa Urzędu Budownictwa Naziemnego, Martin Kießling, napisał: „Nowy Rynek został ukształtowany przez mego poprzednika prof. Fischera ([obecnie] Hanower). Nadał on placowi godną uwagi formę z oryginalnym oddziaływaniem. Domy wreszcie zdołały się uwolnić od schematu, mówiącego 
że w Gdańsku mogą powstawać jedynie domy szczytowe"46. Szczegółowy projekt powstał już po wyjeździe Fischera, przygotowali go pracownicy Urzędu Budownictwa Naziemnego - Schröder i Krüger. Projekty poszczególnych domów opracowało kilku architektów. Prace budowlane prowadzono w drugiej połowie lat dwudziestych XX w. ${ }^{47}$

Obszar miał mieć swój kulminacyjny punkt w formie gmachu szkoły z dużym zapleczem sportowym. Pierwszy projekt można także zapewne wiązać z osobą Fischera, został on przygotowany wspólnie z Krügerem. Gmach szkoły miał powstać przy ul. Pestalozziego (Pestalozziweg). W rozrastającej się dzielnicy nie było szkół, dlatego też przeznaczono na ten cel obszerną działkę. Projekt jest znany jedynie na podstawie ilustracji zamieszczonej $\mathrm{w}$ artykule prasowym ${ }^{48}$ (il. 8).

Zaproponowane rozwiązanie architektoniczne było zgodne $\mathrm{z}$ koncepcjami rozwijanymi w tym czasie przez szefa Urzędu Budownictwa Naziemnego. Gmach główny cofnięto z pierzei ulicy w głąb działki. Przed budynkiem powstało niewielkie wnętrze urbanistyczne, ujęte po bokach poprzez parterowe skrzydła boczne. Dziedziniec oddzielony został od ulicy zielenią (rysunek nie pozwala na jednoznaczną interpretację, czy w projekcie sugerowano wysoki żywopłot). Na zapleczu szkoły, we wnętrzu kwartału zabudowy, umieszczono teren sportowy i szkolny ogród. Gmach główny szkoły miał tradycyjne formy, $\mathrm{z}$ wysokim czterospadowym dachem. Możemy jedynie domniemywać, że elewacje mogły być ceglane.

Przywołany już uprzednio Kießling krytycznie ocenił projekt szkoły, miał on nawiązywać do "gdańskich form”, a „monstrualny dach” stałby się - jego zdaniem - elementem dominującym nad okoliczną zabudową. Kießling zaproponował nowy projekt, który został zrealizowany ${ }^{49}$.

Dwa kolejne projekty to niejako pożegnanie Fischera z Gdańskiem. Pierwszy z nich to projekt gmachu Targów Gdańskich. W dniu 26 stycznia 1925 r., na dwa

46 Martin Kießling, Neue Baugedanken im alten Danzig, „Danziger Zeitung” 1929, Jg. 72, $\mathrm{nr}$ 48, z 17 lutego. Martin Kießling (1879-1944) - architekt, sprawował funkcję dyrektora Urzędu Budowlanego jedynie przez rok, w okresie od marca 1927 r. do marca 1928 r. Kilka jego projektów oraz dwie realizacje budynków szkolnych wywołały duże poruszenie wśród tradycyjnie nastawionego środowiska naukowego Wyższej Szkoły Technicznej i części czynnych w mieście architektów, zob. Ewa Barylewska-Szymańska, Wojciech Szymański, W stronę nowoczesności. Działalność Urzędu Budowlanego Wolnego Miasta Gdańska w latach 1927-1933 (Wybrane zagadnienia) [w:] Modernizm w Europie - modernizm w Gdyni. Architektura XX w. do lat sześćdziesiątych i jej ochrona w Gdyni i w Europie. Urząd Miejski w Gdyni, red. Jolanta Maria Sołtysik, Robert Hirsch, Gdynia 2014, s. 63-68 (tam wcześniejsza literatura); Jacek Friedrich, Walka obrazów. Przedstawienia wobec idei w Wolnym Mieście Gdańsku, Gdańsk 2018, s. 155-161.

47 Archiwum Państwowe w Gdańsku, Państwowy Urząd Policji Budowlanej w Gdańsku, sygn. akt 15/1712, Neuer Markt 1, passim.

48 Ein neues Wohnviertel. Am „Neuen Markt“ in Langfuhr, „Danziger Zeitung” 1926, Jg. 69, nr 119, Zweites Blatt z 30 kwietnia.

49 Martin Kießling, Neue Baugedanken im alten Danzig, „Zentralblatt der Bauverwaltung” 1929, Jg. 49, nr 43, s. 698. 
Ewa

Barylewska-

-Szymańska

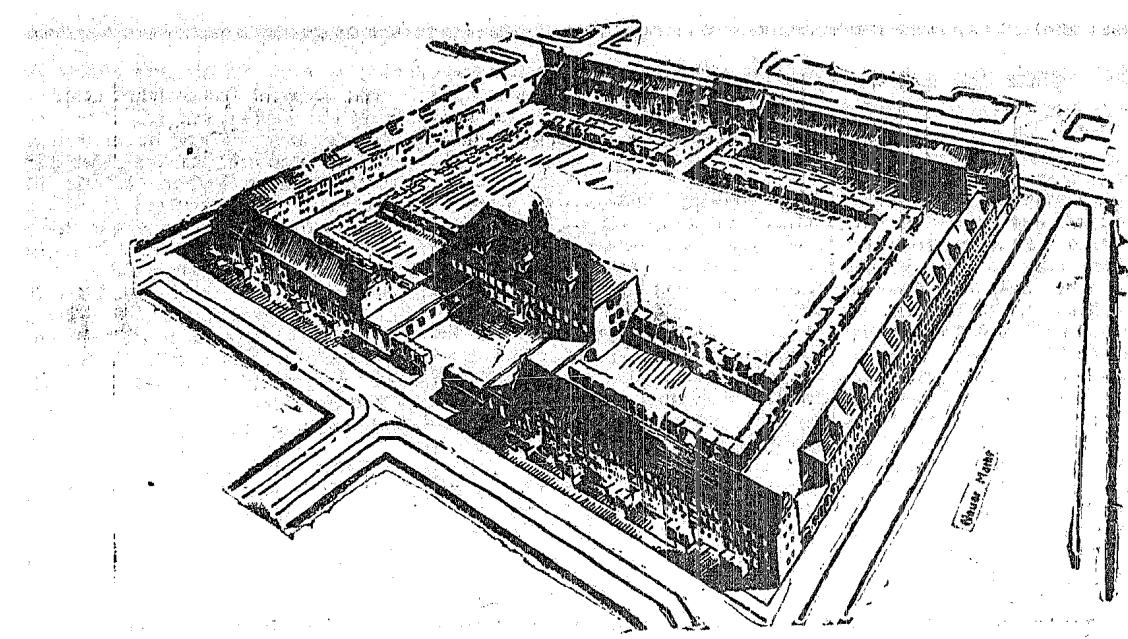

Il. 8. Niezrealizowany projekt szkoły przy ul. Pestalozziego w Gdańsku Wrzeszczu, repr. za: Ein neues Wohnviertel. Am „Neuen Markt“ in Langfuhr, „Danziger Zeitung” 1926, Jg. 69, nr 119, Zweites Blatt z 30 kwietnia

miesiące przed opuszczeniem Gdańska, w siedzibie Towarzystwa Przyrodniczego (Naturforschende Gesellschaft) przy ul. Mariackiej (Frauengasse) szef Urzędu Budownictwa Naziemnego przedstawił zgromadzonej tam publiczności, wśród której byli przemysłowcy i przedstawiciele targów oraz osoby z Wyższej Szkoły Technicznej, plan gmachu targów (Messepalast) ${ }^{50}$ (il. 9). Dyskusję nad wzniesieniem budowli prowadzono kilka lat. Gdańskie Targi wykorzystywały w tym czasie budynki (baraki) należące uprzednio do wojska, położone po przeciwnej stronie szkoły św. św. Piotra i Pawła oraz Biblioteki Miejskiej. Jednak trudna sytuacja ekonomiczna sprawiała, że ostatecznej decyzji nie podejmowano. Projekt Fischera przewidywał wzniesienie gmachu na wskazanym wyżej terenie, oddalonym zaledwie kilka minut drogi od Dworca Głównego. Zabudowa miała objąć pierzeję ul. Doki (Werftgasse), ul. Gazowniczej (Jakobs-Wall), pl. Hanzy (Hansa-Platz, ob. nie istnieje), ul. Wałową (Wallgasse) i ul. Łagiewniki (Schüsseldamm). Główne wejście usytuowano od pl. Hanzy. Ceglane, nowoczesne elewacje nawiązywały do północnoeuropejskich ekspresjonistycznych realizacji tego czasu. Fischer wprowadził rzeźby wieńczące część elewacji (np. fasadę od pl. Hanzy oraz fragment elewacji od ul. Doki).

Program użytkowy, poza salami wystawowymi, zakładał lokale dla sklepów, restauracji oraz salę widowiskową. Wygospodarowano też pomieszczenia dla Szkoły Handlowej. Na najwyższej kondygnacji Fischer zaplanował mieszkania.

50 [Friedrich] Fischer, Das Messehaus für Danzig, „Zentralblatt der Bauverwaltung” 1925, Jg. 45, nr 31, s. 373, il. 5, s. 378. Wykorzystano notę Budynek Targów Gdańskich przy Hansa-Platz, autorstwa Wojciecha Szymańskiego, przeznaczoną do Atlasu architektury Gdańska (w przygotowaniu). 


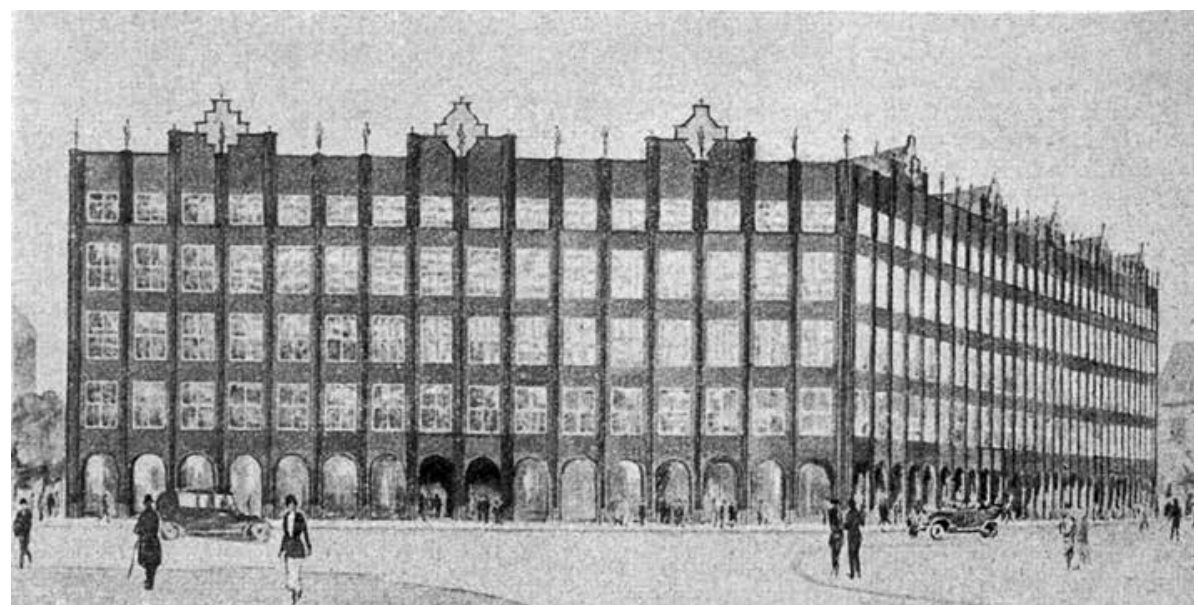

Działalność

architekta

Friedricha

Fischera...

Il. 9. Niezrealizowany projekt gmachu Targów Gdańskich autorstwa Friedricha Fischera, repr. za: Friedrich Fischer, Das Messehaus für Danzig, „Zentralblatt der Bauverwaltung” 1925, Jg. 45, nr 31

Gmach miał być nakryty częściowo płaskim dachem a w częściach, w których przewidywano poddasza - dachami dwuspadowymi, ukrytymi za wyższymi partiami elewacji.

Takie usytuowanie gmachu spowodowało konieczność skorygowania układu pl. Hanzy. Fischer rozwiązał tę kwestię, przedkładając projekt urbanistyczny $\mathrm{z}$ aleją wiodącą do gmachu, tędy miała też przebiegać linia tramwajowa ${ }^{51}$.

Kolejny projekt wstępny z początku 1925 r. również nie doczekał się kontynuacji - architekt zaproponował nową funkcję dla Wielkiej Zbrojowni, która po przebudowie miała stać się siedzibą Państwowego Muzeum Przyrodniczego i Prehistorycznego (Staatliches Museum für Naturkunde und Vorgeschichte) ${ }^{52}$. Muzeum od lat miało problemy lokalowe, a pozostający w gestii wojska obiekt historyczny stracił w nowej sytuacji politycznej właściciela i stał się własnością komunalną. Fischer planował budowę windy towarowej, dostawionej do elewacji od ul. Tkackiej (Wollwebergasse). Na poziomie drugiej kondygnacji wydzielił dużą salę ekspozycyjną oraz niewielką salę wykładową. Kolejna kondygnacja miała służyć jako zaplecze techniczne i biurowe, tu też zaplanowano pomieszczenie dla biblioteki oraz mieszkanie dozorcy.

W okresie urzędowania Fischer zaprojektował trzy kościoły katolickie. Po zakończeniu pierwszej wojny światowej przybywało w Gdańsku ludności tego wyznania, stąd też liczba świątyń okazała się niewystarczająca. Kościół św. Antoniego powstał w Brzeźnie. Katolicy z tej dzielnicy nadal korzystali z poklasztornego kościoła w Oliwie. Projekt powstał na początku lat dwudziestych XX w.

$51 \quad$ Fischer, Das Messehaus..., s. 373, il. 1.

52 Zob. Ewa Barylewska-Szymańska, Muzealna topografia Gdańska w XIX i pierwszych dekadach XX wieku (do roku 1945) [w:] Teraźniejszość przeszłości. Muzealnictwo i historiografia w Gdańsku i na Pomorzu do roku 1945, red. Ewa Barylewska-Szymańska (w druku). 
Ewa we współpracy z Krügerem i dyplomowanym inżynierem Wernicke. W latach Barylewska-Szymańska 1922-1924 trwały prace budowlane, ale już od 1924 r. obiekt użytkowano, chociaż jego konsekracja miała miejsce dopiero w 1926 r. Prace przy budowie prowadzono przy zaangażowaniu miejscowej społeczności - pracowali tu katolicy z Brzeźna, a także z innych gdańskich dzielnic i Sopotu.

Fischer zaprojektował tradycyjną $\mathrm{w}$ formie świątynię, jednocześnie odpowiadającą duchowi czasu - silnie zmodernizowaną i uproszczoną (il. 10). Powstał trójnawowy korpus, z jednonawowym, niższym prezbiterium zamkniętym wielobocznie. Bryła otrzymała tynkowane elewacje, ze zdwojonymi oknami zamkniętymi półkoliście. W prezbiterium umieszczono okrągłe okna. Jedyną artykulację fasady, poza prostym portalem, stanowią blendy. Kościół nakryto wysokim ceramicznym dachem z wysoką, smukłą sygnaturką. We wnętrzu arkady, wsparte na filarach, rozdzielały trzy nawy, w części zachodniej zlokalizowano emporę organową. W prostym, oszczędnym wnętrzu zastosowano drewniany strop. Na południe od kościoła powstał budynek plebanii ${ }^{53}$.

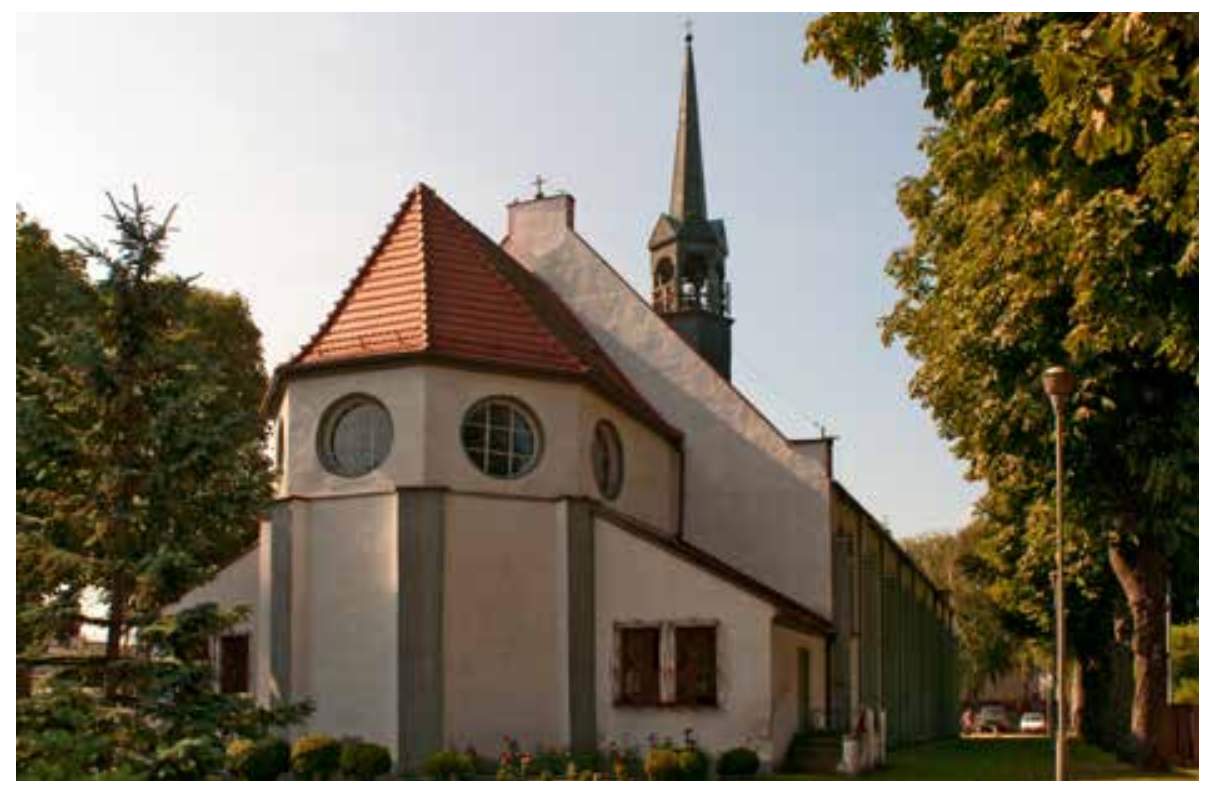

Il. 10. Kościół św. Antoniego w Gdańsku Brzeźnie, fot. Andrzej Mikliński, 2012

Kościół pod wezwaniem Chrystusa Króla Fischer zaprojektował dla katolików z Piekła, niewielkiej miejscowości położonej na terenie dawnego powiatu

53 Paul Schütz, Kennst Du Deine Kirche? Was die Brösener St. Antonius-Kirche erzählt, Danzig [1926]; Weihe der St. Antoniuskirche in Brösen, „Danziger Neueste Nachrichten” 1926, Jg. 33, nr 137, 1. Beilage z 15 czerwca. 
Wielkie Żuławy, na ówczesnych rubieżach Wolnego Miasta (il. 11). Kościół budowano już po wyjeździe architekta do Hanoweru. Ostatecznie świątynię oddano do użytku w 1932 r. Powstała niewielka, ceglana trójnawowa, oszkarpowana budowla, $\mathrm{z}$ wyodrębnioną wieżą w elewacji zachodniej (górna część wieży w konstrukcji szkieletowej). Wielobocznie zamknięte prezbiterium otrzymało okna o analogicznym, jak w kościele św. Antoniego, okrągłym kształcie i takiej samej stolarce. Forma architektoniczna świątyni stanowi odwołanie do kościołów żuławskich, ale i tu architekt prowadził dialog z tradycyjną architekturą ceglaną - zastosował uproszczenia bryły ${ }^{54}$.

Dla gdańskiego kościoła katolickiego, obecnie pod wezwaniem Matki Boskiej Bolesnej (wcześniej Liebfrauenkirche), przy ul. Głębokiej (Niedere Front) Fischer przygotował projekt wstępny ${ }^{55}$. Świątynia powstała na posesji położonej pomiędzy opływem Motławy a ul. Głęboką (il. 12).

Kościól, podobnie jak ten w Piekle, wzniesiono już po wyjeździe architekta. Prace prowadzono w latach 1925-1928 według szczegółowych projektów architekta Felixa Tiedego. Fischer uczestniczył jednak w konsultacjach dotyczących ostatecznego kształtu świątyni.

Zbudowano trójnawowy, halowy kościół z wielobocznie zamkniętym prezbiterium. Ceglana, odwołująca się do gotyckich form, świątynia, została opięta szkarpami i przekryta wysokim dachem, z wysmukłą sygnaturką pośrodku kalenicy. Ze względów oszczędnościowych zrezygnowano z wieży. Fasadę wieńczy schodkowy szczyt $\mathrm{z}$ tynkowanymi blen-

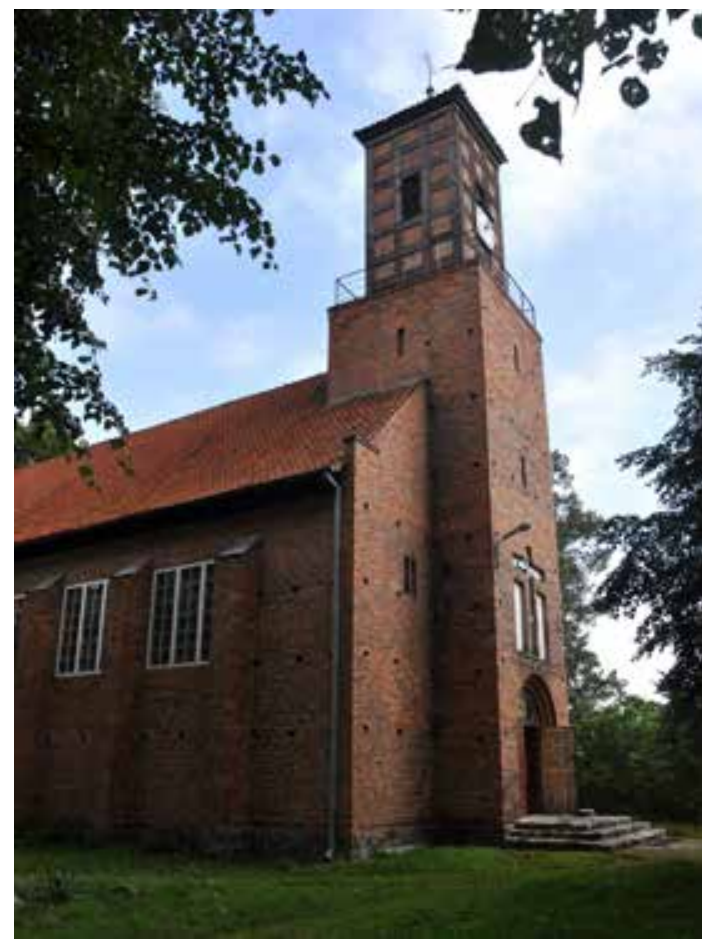

Il. 11. Kościół Chrystusa Króla w Piekle, fot. Adam Fleks, 2012 dami, jedynym elementem ożywiającym gładką, ceglaną powierzchnię jest usytuowany poniżej ostrołukowy, uskokowo cofnięty w głąb portal. Gotyckie formy zostały zmodernizowane i twórczo przekształcone - uzyskano bardzo interesujący efekt, a dodatkowym atutem jest malownicza lokalizacja świątyni.

54 Die neue katholische Kirche in Pieckel, „Danziger Neueste Nachrichten” 1932, Jg. 39, $\mathrm{nr} 134, \mathrm{z} 10$ czerwca.

55 Wykorzystano notę Kościół Matki Boskiej Bolesnej (d. Liebfrauenkirche) przy Niedere Front (ob. ul. Głęboka) autorstwa Wojciecha Szymańskiego, przeznaczoną do Atlasu architektury Gdańska (w przygotowaniu). 


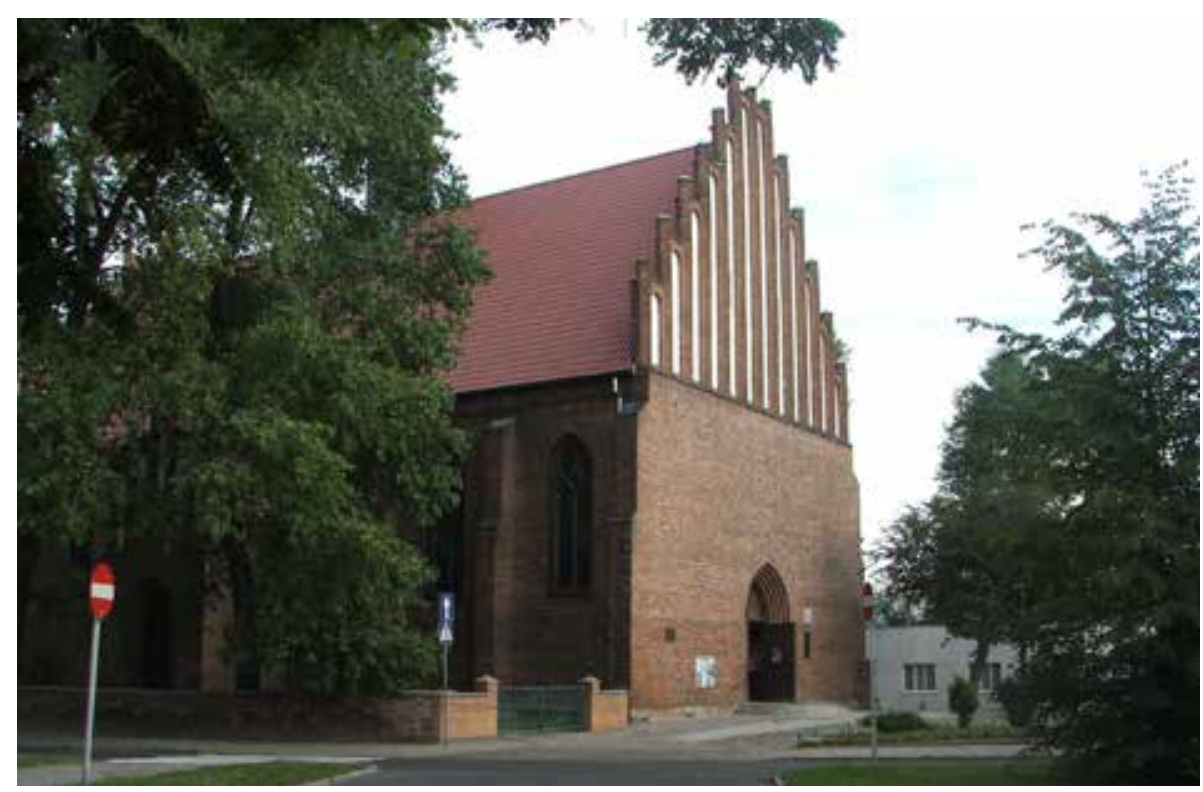

Il. 12. Kościół Matki Boskiej Bolesnej w Gdańsku, fot. Adam Fleks, 2012

Warta odnotowania jest także działalność Fischera na polu konserwatorskim. Najważniejszym zadaniem było zachowanie historycznego śródmieścia. Problem ten powracał, w różnym natężeniu, w dyskusjach prowadzonych w gronie fachowców w okresie istnienia Wolnego Miasta Gdańska. Stał się on jednym z najważniejszych przejawów zachowania kulturowej tożsamości Gdańska, postrzeganej jako walka o niemieckie status quo. Fischer włączył się do tych działań ${ }^{56}$. Zachowanie całościowego „obrazu miasta” polegało, według niego i generacji jego poprzedników, przede wszystkim na ocaleniu całych kwartałów ulic, zabudowanych ustawionymi szczytowo kamienicami. Obrazu miasta dopełniały górujące nad zabudową mieszczańską obiekty sakralne i municypalne. Fischer miał silne wsparcie prof. Otto Kloeppla, który stał w tym czasie na czele Rady Zabytków (Denkmalrat) i podzielał opinię o konieczności ochrony całego zespołu miejskiego ${ }^{57}$.

56 „Danzig besitzt ein Stadtbild von bedeutsamer Eigenart und außerordentlicher Schöheit [...], dessen Erhaltung jedem Städtebauer und jedem Kunstfreund heiß am Herzen liegen muß”, zob. A.G., Die Erhaltung des Danziger Stadtbildes. Nach einem vom Oberbaurat Professor Dr. Friedrich Fischer in Danzig auf der 35. Abgeordnetenversammlung des Verbandes Deutscher Architekten- und Ingenieurvereine in Danzig gehaltenen Vortrag, „Zentralblatt der Bauverwaltung” 1923, Jg. 43, nr 85/86, s. 511-513. Zob. też: B. Pusback, Stadt als Heimat. Die Danziger Denkmalpflege zwischen 1933 und 1939, Köln-Weimar-Wien 2006, s. 208-209, 216.

57 Muzeum Narodowe w Gdańsku, Archiwum, Akte Denkmalrat [1923-1927], syng. akt MNG/A/VI/10, protokół z posiedzenia w dniu 28 stycznia $1925 \mathrm{r}$. 
Zachowanie urbanistycznego kompleksu historycznej zabudowy centrum Gdańska wydawało się u progu istnienia Wolnego Miasta zagrożone. Nawet korzystne uregulowania prawne chroniły jedynie wybitne pojedyncze obiekty. Natomiast te mniej znaczące, oddziałujące jednak na całościowy obraz, pozostawały bez opieki konserwatorskiej. Tymczasem w wyniku zmian gospodarczych przechodziły one w ręce nowych właścicieli planujących modernizację, a nierzadko także daleko idące przekształcenia fasad. Często też planowano zastępować istniejące obiekty nowymi realizacjami, co musiało prowadzić do zmiany charakteru historycznego centrum.

W związku z tym Fischer rozwinął koncepcję mającą na celu zapobieżenie takiej sytuacji. Podobnie jak na przełomie XIX i XX w., gdy rozebrano nowożytne obwałowania, a w ich miejscu wytyczono arterie komunikacyjne, przy których powstała współczesna zabudowa ${ }^{58}$, należało i tym razem wyznaczyć przestrzeń rozwoju. Fischer zaproponował wzniesienie nowej dzielnicy handlowej, miała się ona rozpościerać od Bramy Oliwskiej (Oliver Tor) w kierunku wytyczonych wcześniej na terenach pofortyfikacyjnych ulic i obejmować również obszar częściowo już zabudowany, aż do ul. Okopowej (Wiebenwall). Odpowiednie połączenia drogowe, omijające ścisłe centrum, miały zapewnić komunikację z portem i zapleczem miasta (zwłaszcza z Żuławami).

Główne Miasto, które w planach Fischera nadal stanowiło „serce miasta" ${ }^{\text {, }}$, miało jednak ulec istotnym przekształceniom - z dzielnicy mieszkaniowej w dzielnicę handlową. Architekt zaproponował powołanie do życia towarzystwa mającego doprowadzić do przekształcenia funkcji domów (Gesellschaft zur Ausgestaltung). Pierwszym obszarem eksperymentalnym miała być ul. Piwna (Jopengasse). Towarzystwo miało budować na tańszych terenach poza centrum nowe mieszkania spełniające współczesne standardy - odpowiednio nasłonecznione i dobrze przewietrzane, położone wśród zieleni gwarantującej dzieciom miejsce zabaw, a dorosłym wypoczynek. Natomiast domy w centrum planowano przeznaczyć na biura. Kolejnym celem projektu była renowacja fasad, mająca na celu usunięcie dziewiętnastowiecznych przekształceń i przywrócenie im historycznej formy. W niektórych przypadkach - zdaniem Fischera - możliwe mogło być nawet odtworzenie przedproży. Estetyzacji miały podlegać również wszelkie wywieszki i szyldy reklamowe, które należało umieścić, według jednolitych zasad, w obrębie wejścia do kamienicy. Partery miały zachować funkcje handlowe. Jednak i tu Fischer zaproponował nowe rozwiązanie. Przyziemia planowano nieznacznie wysunąć, co miało wyraźnie wskazywać na ingerencję z późniejszego okresu. Wizualne łączenie lokali użytkowych znajdujących się w dwóch lub trzech kamienicach w jedną całość dawało możliwość stworzenia większych witryn sklepowych,

58 Omilanowska, Defortyfikacja Gdańska..., s. 33-38.

59 W tych opiniach Fischer nie był odosobniony. Podobnego zdania był Cornelius Gurlitt, co wyraził w trakcie Dnia Zabytków w 1911 r., zob. Pusback, Stadt als Heimat..., s. 84, przyp. 289. 
Ewa odpowiadających ówczesnym wymogom handlowym. Przeszklenia znaczBarylewska- nych partii fasad, zmieniające ich charakter, planowano jednak wykluczyć. -Szymańska Rysunek koncepcyjny ukazujący fragment ul. Długiej (Langgasse) pokazuje proponowane przez konserwatora rozwiązania (il. 13).

Fischer wcielił opisane zasady podczas prac przeprowadzonych w siedzibie Dresdner Bank przy Długim Targu (Langer Markt) 12/13. Autorem projektu

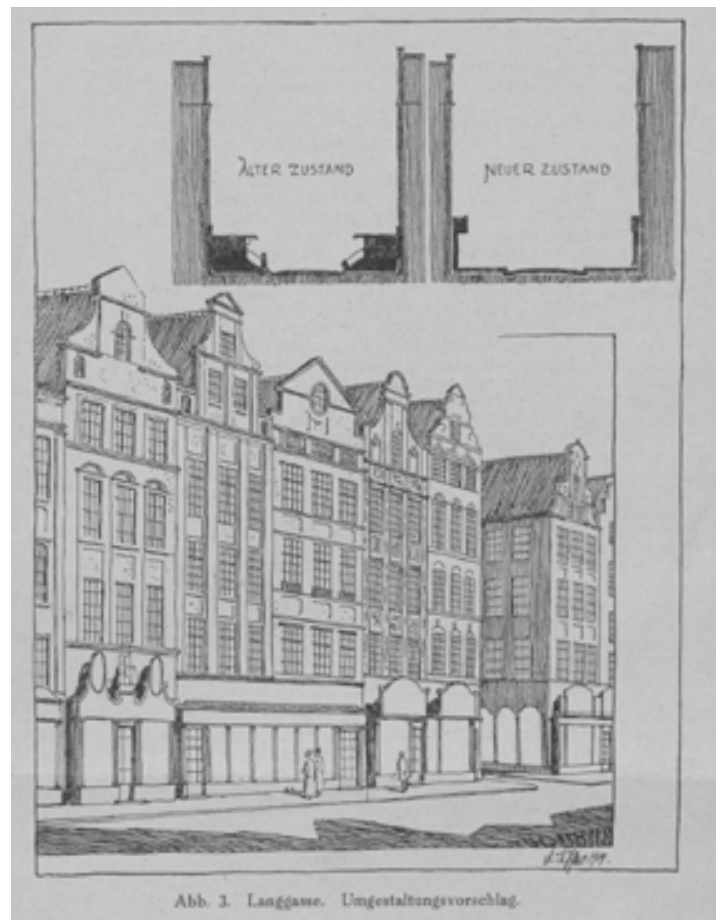

Il. 13. Propozycja przekształcenia ul. Długiej, około 1923, repr. za: A.G., Die Erhaltung des Danziger Stadtbildes. Nach einem vom Oberbaurat Professor Dr. Friedrich Fischer in Danzig auf der 35. Abgeordnetenversammlung des Verbandes Deutscher Architekten- und Ingenieurvereine in Danzig gehaltenen Vortrag, „Zentralblatt der Bauverwaltung” 1923, Jg. 43 , nr $85 / 86$ był gdański architekt Tiede. Obie fasady sąsiadujących ze sobą kamienic zostały przekształcone już w XIX w. Na podstawie Akt Policji Budowlanej można prześledzić ewolucję koncepcji ukształtowania fasad ${ }^{60}$. W tym kontekście najbardziej interesujący jest niezrealizowany ostatecznie projekt z nowoczesnymi szczytami, które w późniejszym okresie były chętnie stosowane w Gdańsku. Projekt ten powstał niewątpliwie pod silnym wpływem koncepcji Fischera i uzyskał akceptację - jak wynika z przedłożonego do Policji Budowlanej pisma.

Tiede ujednolicił oba szczyty, nadając im nową, współczesną formę (il. 14). Obie trójosiowe fasady otrzymały analogiczny wygląd, osiągnięty poprzez gładką powierzchnię opracowanych tak samo kolorystycznie ścian, ożywionych jedynie wąskimi opaskami okiennymi, oraz poprzez zastosowanie jednorodnej stolarki okiennej o drobnych podziałach. W przyziemiu, zgodnie z propagowaną przez Fischera zasadą, obie fasady połączono funkcjonalnie, stosując duże powierzchnie okien o drobnych podziałach i jednorodną stolarkę drzwiową, przestrzeń pomiędzy drzwiami wykorzystano na tablicę informacyjną wpasowującą się w rytm podziałów okiennych.

60 Architekt przygotował w 1921 r, pierwszą wersję projektu, rok później powstała zmieniona wersja („[eine] Zeichnung zur Veränderung der Fassaden”). Ta została zaakceptowana („Professor Fischer [hat] bereits sein Einverständnis zur Ausführung der Fassade in dieser Form gegeben”), zob. Archiwum Państwowe w Gdańsku, Akta Policji Budowlanej, sygn. akt 15/2798, s. 111, 112, $116,117,154,170-178 ; 15 / 2799$, s. 33, 72, 74. 
Wydaje się, że Tiede zrealizował zasady ściśle opracowane przez konserwatora zabytków, dlatego zapewne realizacja ta została włączona do dorobku Fischera ${ }^{61}$.

Hermann Schmitz bardzo pozytywnie ocenił efekt przeprowadzonych prac ${ }^{62}$. Uznał, że to właśnie ta realizacja wytyczyła nowe drogi ochronie zabytków, ponieważ doprowadziła do korzystnej koegzystencji form współczesnych $\mathrm{z}$ historycznymi. Inaczej było natomiast na forum ogólnoniemieckim - podczas Dnia Zabytków w 1928 r. tego rodzaju podejście poddano krytyce ${ }^{63}$. Kießling, następca Fischera, także skrytykował stosowanie atrap szczytów, uznając je nawet za „wieczną chorobę”, która w Gdańsku rozprzestrzenia się aż po obrzeża miasta ${ }^{64}$.

Do realizacji Dresdner Bank w Gdańsku jednak powracano, jak choćby na początku lat trzydziestych XX w. Jednym z przykładów jest remont konserwatorski dwóch kamienic usytuowanych na rogu ulic Długie Ogrody (Langgarten) i Łąkowej (Weidengasse). Projekt autorstwa Henry Brettschneidera powstał w 1929 r., jednak proces zatwierdzania planów, a następnie ich realizacja przeciągnęły się aż do kwietnia 1933 r. W artykule prasowym, w którym omawiono wykonane prace, wyraźnie wskazywano na zalecenia Fischera. Przyziemie kamienic połączono funkcjonalnie, unowocześniono i oddzielono od wyższych kondygnacji szerokim gzymsem. W zastosowanym barwnym

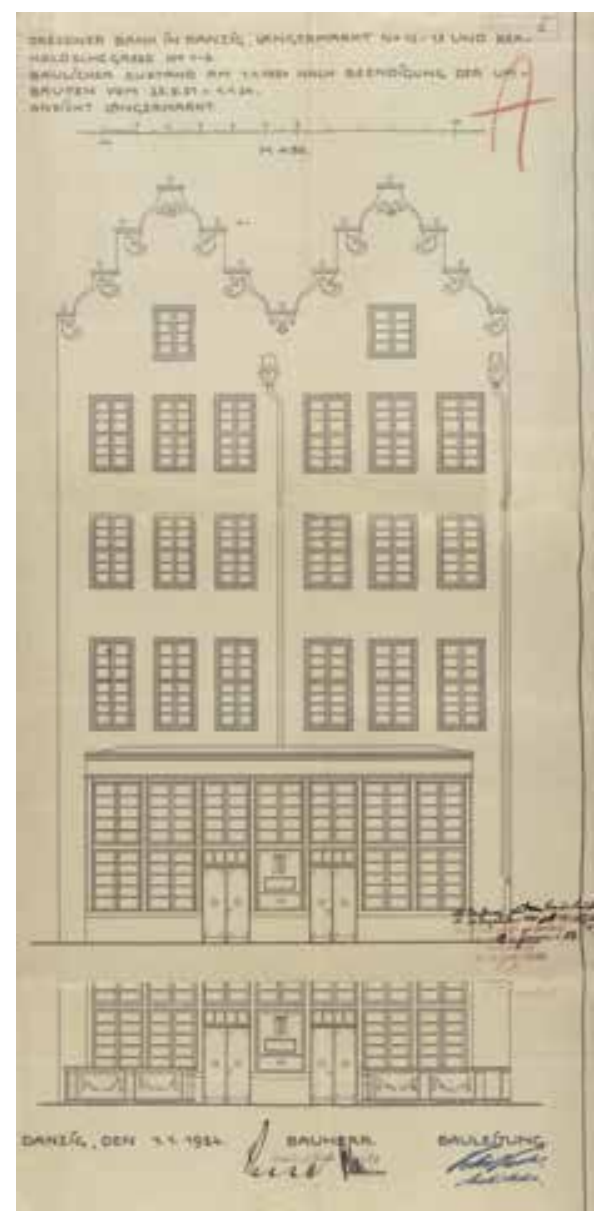

Il. 14. Inwentaryzacja fasad Dresdner Bank po przebudowie przy ul. Długi Targ 12-13, Archiwum Państwowe w Gdańsku, sygn. $15 / 2798$

${ }^{61}$ Np. Schmitz, Die Bautätigkeit Fischers..., s. 134-135; Kurt Frick, Danzig stellt sein Stadtbildwieder her. Erneuerung und Umgestaltung von Giebelhäusern durch Architekten Dipl.-Ing. Heinz Bahr, „Deutsche Bauzeitung” 1936, Jg. 70, H. 3, s. 48.

62 „Die beiden Giebel [...] fügen sich, obzwar von völlig neuartiger Linienführung, organisch dem Rhythmus der Nachbarn[häusern]. [...] Überraschend ist aber besonders das selbstverständliche Zusammenwirken der in ganz modernen sachlichen Formen gehaltenen Ladenvorbauten mit der älteren, durch die steinernen Beischläge belebten Umgebung", zob. Schmitz, Die Bautätigkeit Fischers..., s. 135.

${ }_{63}$ Zob. Gustav Lampmann, Die Krise im Denkmal- und Heimatschutz. Zur Tagung des Bundes für Denkmalpflege und Heimatschutz vom 3. bis 8. September 1928 in Würzburg und Nürnberg, „Zentralblatt der Bauverwaltung” 1928, Jg. 48, H. 40, s. 641-644.

64 Kießling, Neue Baugedanken..., s. 699. 
Ewa opracowaniu elewacji także odwołano się do doświadczeń Fischera z prac przy Barylewska-Szymańska ul. Długiej i Długim Targu ${ }^{65}$.

Wkrótce po przejęciu władzy przez hitlerowców w maju 1933 r. ruszył szeroko zakrojony program „rekonstrukcji” historycznego obrazu miasta. Profesor Kloeppel, autor programu, sprawujący wówczas funkcję konserwatora (Staatlicher Denkmapfleger für Baukunst), był orędownikiem zachowania historycznego centrum jako całości ${ }^{66}$. Zaproponowane na początku lat dwudziestych XX w. przez Fischera formy zostały wówczas zaakceptowane i uznane za dobry punkt odniesienia ${ }^{67}$. Nie pozostawiono wprawdzie jego propozycji wysunięcia przyziemia, jednak partery z dużymi powierzchniami okien nadal zachowały nowoczesny charakter. A jednolicie ukształtowane wystawy obejmowały kilka kamienic, tak by w pełni zrealizować cele handlowe ${ }^{68}$. Dobrym przykładem porównawczym dla Dresdner Bank jest projekt architekta Heinza Bahra, wykonany dla sklepu Leisera przy ul. Długiej $73-74^{69}$.

Fischer opracował wzornik kolorystyczny (il. 15). Preferowana była kolorystyka z użyciem żółcieni oraz tonacji morsko-zielonej („seegrüne Tönen”). Wydaje się jednak, że zalecając nowe pomalowanie fasad, nie odnoszono się do odkrywek dawnych warstw malarskich. Właściciele mogli wybrać spośród trzech podstawowych kolorów, które akceptował Urząd Konserwatorski. Natomiast zastosowanie innej kolorystyki wymagało uzgodnienia z odpowiednimi władzami. W trakcie przeprowadzanych prac Fischer nadzorował usuwanie uzupełnień i zmian, których dokonano w XIX i na początku XX w., starając się o powrót do historycznego wyglądu fasady. Szczególną uwagę architekt poświęcał przywracaniu pierwotnego wyglądu elewacjom ceglanym, bowiem bardzo często były one tynkowane (zwłaszcza w XIX w. i na początku XX w.), przez co zatracały swój pierwotny charakter.

Na przywołanie zasługuje również restauracja kamienicy przy ul. Długiej, w bezpośredniej bliskości głównomiejskiego Ratusza, będącej siedzibą Miejskiej Kasy Oszczędnościowej (Städtische Sparkasse). Pracom poddano również fasady kamienic przy Długim Targu, usytuowane na odcinku pomiędzy ulicami Kramarską (Große Krämergasse) i Kuśnierską (Kürschnergasse).

Fischer zajął się także przedprożami. Ustawiono je w niektórych brakujących miejscach przy Długim Targu. Wykorzystano do tego celu zachowane fragmenty,

65 Die neue Ecke Langgarten-Weidengasse, „Danziger Neueste Nachrichten” 1933, Jg. 40, nr 84 z 8-9 kwietnia. Opracowane na podstawie noty Dom mieszkalny i kawiarnia Langgarten autorstwa Wojciecha Szymańskiego, przeznaczonej do Atlasu architektury Gdańska (w przygotowaniu do publikacji).

66 „eine Art Museumstraße des alten Stadtbildes”, zob. Otto Kloeppel, Die Wiederherstellung des alten Stadtbildes von Danzig seit der national Erhebung. I. Die Arbeiten des Jahres 1934 (Die Baukunst im Deutschen Osten. Beiträge zu ihrer Gestaltungsentwicklung, Hg. Architekturabteilung der Technischen Hochschule Danzig), [Danzig 1935], s. 12.

67 Pusback, Stadt als Heimat..., s. 209.

68 Ibidem, s. 227.

69 Kloeppel, Die Wiederherstellung des alten Stadtbildes..., s. 19, XIX-XX. 


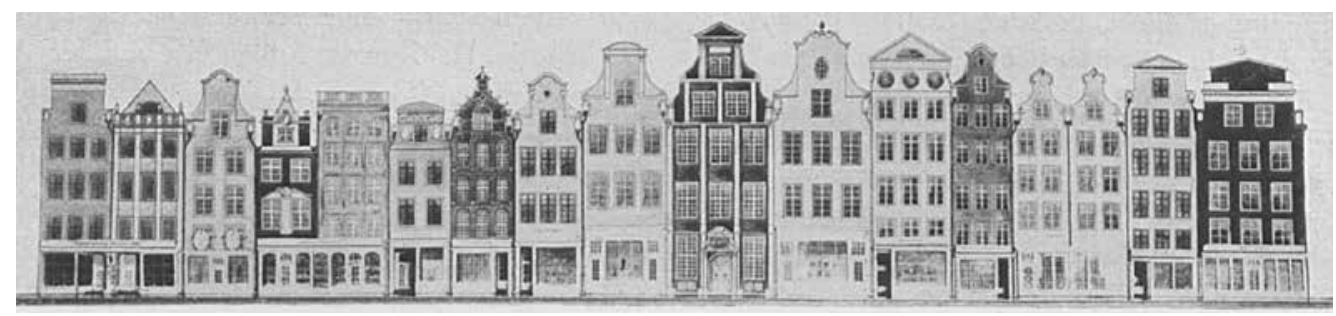

Il. 15. Projekt kolorystyki ul. Długiej w Gdańsku, około 1923, repr. za: Herrmann Schmitz, Die Bautätigkeit Fischers im Freistaate Danzig, „Zeitschrift für bildende Kunst” 1924/1925, Jg. 58

zapewne je uzupełniając. Zabiegom konserwatorskim poddano portale przy Długim Targu 10, 40 i 42 oraz przy ul. Długiej (numery domów nie zostały podane) i św. Ducha (siedziba Deutsches Volkshaus). Natomiast Dom Angielski, przy ul. Chlebnickiej (Brodbänkengasse) 16, stanowiący od 1912 r. własność miasta, można było jedynie wzmocnić konstrukcyjnie ${ }^{70}$, co gwarantowało jego przetrwanie w oczekiwaniu na korzystniejszą sytuację finansową, umożliwiającą przeprowadzenie pełnego zakresu prac.

Fischer $\mathrm{w}$ prowadzonych $\mathrm{w}$ ramach urzędu pracach koncentrował się przede wszystkim na architekturze świeckiej. Jednak konserwacji poddano także kilka kościołów: św. Trójcy, w którym przeprowadzono renowację zachodniego szczytu świątyni, św. Bartłomieja (tu zabiegi dotyczyły wschodniego szczytu) a także szczyt kościoła św. Ignacego na Starych Szkotach ${ }^{71}$.

Niemal bezpośrednio po utworzeniu Wolnego Miasta przystąpiono do prac nad ustawą o ochronie zabytków i przyrody (Denkmal- und Naturschutzgesetz). Prowadził je w Senacie Oddział ds. Nauki, Sztuki i Oświaty (Abteilung für Wissenschaft, Kunst und Volksbildung) ${ }^{72}$. Pierwszy ślad prac nad ustawą pochodzi z lipca 1921 r., natomiast pismo skierowane do Zgromadzenia Ludowego (Volkstagu, czyli ówczesnego gdańskiego parlamentu), zawierające projekt ustawy i prośbę o skierowanie jej do uchwalenia, nosi datę 9 sierpnia $1922 \mathrm{r}$.

$\mathrm{W}$ trakcie ponadrocznych prac nad ustawą powołano grono ekspertów, którzy przygotowali poszczególne paragrafy. W skład tego gremium weszli m.in. dyrektorzy Biblioteki Miejskiej - początkowo Otto Günther ${ }^{73}$, a następnie Friedrich Schwarz ${ }^{74}$, oraz Archiwum Wolnego Miasta - Karl Josef Kaufmann ${ }^{75}$. W pracach uczestniczyli również konserwatorzy branżowi: do spraw zabytków

$70 \quad$ Bericht über die Verwaltung..., s. 124.

${ }_{71}$ Ibidem; Erich Keyser, Die Baugeschichte der Stadt Danzig, Köln-Wien 1972, s. 487.

72 Archiwum Państwowe w Gdańsku, Akta Senatu WMG, sygn. akt 260/3602, s. 10-66.

73 Otto Günther (1864-1924) - bibliotekarz, w latach 1912-1921 dyrektor Biblioteki Miejskiej, zob. Marek Andrzejewski, Ludzie Wolnego Miasta Gdańska (1920-1939), Gdańsk 1997, s. 45.

${ }^{74}$ Friedrich Schwarz (1875-1968) - bibliotekarz, w latach 1922-1935 dyrektor Biblioteki Miejskiej, zob. Andrzejewski, Ludzie Wolnego Miasta..., s. 100; Mirosław Gliński, Friedrich Schwartz, www.gedanopedia.pl [dostęp: 27.06.2021 r.].

75 Karl Josef Kaufmann (1865-1945) - historyk, archiwista, w latach 1921-1929, dyrektor gdańskiego archiwum, zob. Andrzejewski, Ludzie Wolnego Miasta..., s. 55. 
Ewa architektonicznych - prof. Fischer, oraz dzieł sztuki i rzemiosła artystyczBarylewska-Szymańska nego - dr Hans Friedrich Secker ${ }^{76}$, a w końcowej fazie dr Walter Mannowsky, który w lipcu 1922 r. zastąpił swego poprzednika ${ }^{77}$. Dwaj ostatni pełnili również funkcję dyrektorów Muzeum Miejskiego.

Zachowana fragmentarycznie korespondencja dokumentuje odbywające się narady i konsultacje oraz przekazywane do zaopiniowania poszczególne fragmenty ustawy.

Ustawa weszła w życie w dniu 6 lutego $1923 \mathrm{r} .{ }^{78}$ Dawała możliwość ochrony poszczególnych obiektów dzięki wpisaniu ich na listę zabytków. Wstępna lista, na której powstanie istotny wpływ miał konserwator zabytków architektonicznych, została przygotowana w latach 1924-1925. Ujęto na niej bardzo wiele kamienic mieszczańskich, przy niektórych ulicach wpisano je na listę niemal kompletnie, na przykład kamienice przy ul. Mariackiej (Frauengasse) $)^{79}$.

Fischer prowadził również, z racji pełnionej funkcji, prace inwentaryzacyjne, jednak brak jest danych na ten temat, w sprawozdaniu za lata 1920-1925 skwitowano to zadanie zaledwie jednym zdaniem informującym o rozpoczęciu prac ${ }^{80}$.

Wydaje się, że w związku z prowadzonymi pracami inwentaryzacyjnymi i sporządzaniem rejestru zabytków Fischer interesował się także wnętrzami gdańskich kamienic. Ślad tego odnajdujemy w interesującym przyczynku na temat osiemnastowiecznego wystroju jednej z kamienic przy ul. Mariackiej ${ }^{81}$.

W tekście przypomniana została sylwetka Friedricha Fischera, wskazano realizacje z okresu jego działalności jako prywatnego architekta z Gdańska i Sopotu oraz prace projektowe prowadzone $w$ ramach Urzędu ds. osiedli, a następnie Urzędu Budownictwa Naziemnego. Jego projekty (również te niezrealizowane) sytuują go w rzędzie architektów odwołujących się do północnoniemieckiej tradycji architektonicznej, do nurtu architektury reformy, a stosowane przez niego formy są zmodernizowane i twórczo zinterpretowane.

76 Hans Friedrich Secker (1888-1960) - historyk sztuki, zatrudniony w gdańskim Muzeum Miejskim od 1912 r., funkcję dyrektora sprawował w latach 1916-1922, zob. Mirosław Gliński, Secker Hans Friedrich [w:] Encyklopedia Gdańska, red Błażej Śliwiński, [Gdańsk] 1912, s. 919.

77 Walter Mannowsky (1881-1958) - historyk sztuki, muzealnik, w latach 1922-1938 dyrektor Muzeum Miejskiego w Gdańsku, zob. Andrzejewski, Ludzie Wolnego Miasta..., s. 72.

78 Gesetz betreffend den Denkmal- und Naturschutz. Vom 6 Februar 1923, „Gesetzblatt für die Freie Stadt Danzig" 1923, Nr 16, s. 245.

79 Muzeum Narodowe w Gdańsku, Archiwum, Akte Denkmalrat [1923-1927], sygn. akt MNG/A/VI/10, s. 5 .

${ }^{80}$ „die durch das Denkmalschutzgesetz vorgeschriebene Katalogisierung der Bauund Kunstdenkmäler ist eingeleitet”, zob. Bericht über die Verwaltung..., s. 124. Katja Bernhardt, Inwentaryzacja zabytków sztuki między nauką i polityką: Prusy Zachodnie $i$ Wolne Miasto Gdańsk, „Biuletyn Historii Sztuki” 2010, R. 72, nr 3, s. 281-282.

81 F[riedrich] Fischer, Treppenanlage im Hause Frauengasse 9 in Danzig, „Zentralblatt der Bauverwaltung" 1925, Jg. 45, nr 11, s. 126-127. 
Schmitz opisując dokonania Fischera, widział go w gronie takich architektów, jak Heinrich Tessenow czy Paul Schmitthenner. Obaj byli uznanymi reformatorami architektury, propagowali i realizowali w swoich projektach ideę miast ogrodów, a jednocześnie reprezentowali nurt budownictwa odwołujący się do tradycji ${ }^{82}$. Opinia ta jest słuszna, a grono architektów wśród, których sytuuje się Fischer, można poszerzyć o kolejne nazwiska, jak choćby Fritz Höger czy Fritz Schumacher. W większości projektów Fischer proponował ceglane elewacje, co wiązało się z osobistym zainteresowaniem architekta. Ceglaną architekturą zajmował się także jako naukowiec, analizując zwłaszcza średniowieczne obiekty sakralne. W Gdańsku stosowanie ceglanych elewacji nowo projektowanych obiektów w tym okresie stało się - jak na to zwrócił uwagę Jacek Friedrich - „przejawem specyficznego lokalnego tradycjonalizmu”83. Działalność Fischera dobrze wpisuje się w ten nurt architektury.

Fischer działał jako Konserwator Zabytków Architektury WMG jedynie przez cztery lata, jednak był to czas wypracowywania wzorców postępowania konserwatorskiego. Nastąpiło wówczas połączenie funkcji Konserwatora Zabytków Architektonicznych i kierującego Urzędem Budownictwa Naziemnego, o takim rozwiązaniu stanowił odpowiedni zapis Ustawy o ochronie zabytków i przyrody. Jednak już w 1926 r., rok po wyjeździe prof. Fischera z Gdańska, kwestie zabytków architektonicznych powierzono młodemu, niedoświadczonemu wówczas jeszcze zawodowo Erichowi Volmarowi ${ }^{84}$, pracującemu w Urzędzie Budownictwa Naziemnego. Nie otrzymał on jednak nominacji na stanowisko konserwatora. Takie rozwiązanie spotkało się z krytyką Fischera, wyrażoną w stanowczych słowach na łamach ogólnoniemieckiego czasopisma architektonicznego „Deutsche Bauzeitung”. Były gdański konserwator uznał takie postępowanie - wobec zadań, jakie stały przed osobami chroniącymi miejscowe zabytki architektury - za nieodpowiedzialne. Proponował pozyskanie innego kandydata mającego przejąć pieczę nad kulturową spuścizną, wskazują przy tym wyraźnie na środowisko profesorów architektury Wyższej Szkoły Technicznej ${ }^{85}$.

82 Schmitz, Die Bautätigkeit Fischers..., s. 139.

83 Friedrich, Walka obrazów..., s. 173. W ten sposób stosowanie cegły postrzegał również Schumacher w Hamburgu, zob. Hermann Hipp, Fritz Schumachers Hamburg: Die reformierte Stadt [w:] Moderne Architektur..., s. 164. Szerzej o odwołaniach do budownictwa ceglanego w północnych Niemczech w nurcie „konserwatywnego modernizmu” zob. Makała, Nawiązania do tradycji nowożytnej..., s. 95, 99.

84 Erich Volmar (1887-1975) - architekt, od 1921 r. pracownik Urzędu Budownictwa Naziemnego Wolnego Miasta Gdańska, od 1926 r. zajmował się zagadnieniami konserwatorskimi, w latach 1939-1945 konserwator zabytków Okręgu Rzeszy Gdańsk-Prusy Zachodnie, zob. Gerhard Lippky, Volmar Erich [w:] Altpeußische Biographie, Bd. 4, Hg. Erich Bahr, Gerd Brausch, Marburg 1984, s. 1299. Na temat powierzenia mu funkcji w 1926 r. zob. Erich Volmar, Danzigs Bauwerke und ihre Wiederherstellung. Ein Rechenschaftsbericht der Baudenkmalpflege, Danzig 1940, s. 18.

${ }_{85}$ Friedrich Fischer, Erhaltung und Pflege der Kunstdenkmäler in Danzig, „Deutsche Bauzeitung" 1926, Jg. 60, nr 75, s. 616. 
Fischer jako konserwator zainicjował przeprowadzenie pierwszych prac renowacyjnych. Jednak przeszkodą $\mathrm{w}$ ich pełnej realizacji była zła sytuacja finansowa Wolnego Miasta Gdańska. W okresie sprawowania przez niego funkcji konserwatora priorytetem stało się zachowanie historycznego obrazu miasta. Wypracowany przez niego wzorzec postępowania na terenie Głównego Miasta stanowił ważny punkt odniesienia w kolejnych latach. Fischer miał wpływ na przygotowywaną Ustawę o ochronie zabytków i przyrody, pracował też nad wykazami historycznych gmachów przewidzianych do wpisania na listę zabytków. Zainicjował również pierwsze, przygotowawcze prace inwentaryzacyjne.

\section{Bibliografia}

Althoff [Hugo], Danzig [w:] Städtebau und Wohnungswesen der Welt. Town planning and housing throughout the world. L'urbanisme et l'habitation dans tous les pays, Hg. Bruno Schwan, Berlin 1935, s. 142-145.

Andrzejewski Marek, Ludzie Wolnego Miasta Gdańska (1920-1939), Gdańsk 1997.

Barylewska-Szymańska Ewa, Friedrich Fischer und die Architekturdenkmalpflege in den Anfängen der Freien Stadt Danzig [w:] Entdecken - Erforschen - Bewahren. Beiträge zur Kunstgeschichte und Denkmalpflege. Festgabe für Sibylle Badstübner-Gröger zum 12. Oktober 2015, Hg. Camilla Badstübner-Kizik, Edmund Kizik, Berlin 2016, s. 286-295.

Barylewska-Szymańska Ewa, Szymański Wojciech, Gdański drapacz chmur, „30 dni” 2007, nr 6 (74), s. 26-34.

Barylewska-Szymańska Ewa, Szymański Wojciech, Konkurs na gdański wieżowiec w 1920 roku [w:] Architektura modernistyczna budynków użyteczności publicznej, Gdańsk 2004, s. 81-84.

Barylewska-Szymańska Ewa, Szymański Wojciech, $W$ stronę nowoczesności. Działalność Urzędu Budowlanego Wolnego Miasta Gdańska w latach 1927-1933 (Wybrane zagadnienia) [w:] Modernizm w Europie - modernizm w Gdyni. Architektura XX w. do lat sześćdziesiątych i jej ochrona w Gdyni i w Europie, red. Jolanta Maria Sołtysik, Robert Hirsch, Gdynia 2014, s. 63-68.

Bericht über die Verwaltung der Stadtgemeinde Danzig vom 1. April 1920 bis 31. März 1925, Hg. Statistisches Landesamt der Freien Stadt Danzig, Danzig 1926.

Berger-Thimme Dorothea, Wohnungsfrage und Sozialstaat. Untersuchungen zu den Anfängen staatlicher Wohnungspolitik in Deutschland (1873-1918), Frankfurt am Main 1976.

Bernhardt Katja, Inwentaryzacja zabytków sztuki między nauką i polityką: Prusy Zachodnie i Wolne Miasto Gdańsk, „Biuletyn Historii Sztuki” 2010, R. 72, nr 3, s. 263-291.

Bernhardt Katja, Stil - Raum - Ordnung. Architekturlehre in Danzig 1904-1945, Berlin 2015.

Borrmann Norbert, Paul Schultze-Naumburg. 1869-1949. Maler, Publizist, Architekt. Vom Kulturreformer der Jahrhundertwende zum Kulturpolitiker im dritten Reich, Essen 1989. 
Cielątkowska Romana, Lorens Piotr, Architektura i urbanistyka osiedli socjalnych Gdańska okresu XX-lecia międzywojennego, Gdańsk 2000.

Fehlhaber K[urt], Danzigs Stadterweiterung, „Danziger Statistische Mitteilungen” 1926, Jg. 6, nr 11, s. 170-171.

Działalność architekta Friedricha Fischera...

Fischer Friedrich, Der Danziger Kirchenbau des 15. und 16. Jahrhunderts (Diss. THD), Danzig 1910.

Fischer [Friedrich], Das Messehaus für Danzig, „Zentralblatt der Bauverwaltung” 1925, Jg. 45 , nr 31, s. 373 , il. 5, s. 378 .

Friedrich Fischer, Erhaltung und Pflege der Kunstdenkmäler in Danzig, „Deutsche Bauzeitung" 1926, Jg. 60, nr 75, s. 616.

Friedrich Fischer, Norddeutscher Ziegelbau, München 1944.

Fink Stefanie, „Brausejahre” in Berlin. Die Architektenausbildung an der Technischen Hochschule Charlottenburg während der Kaiserzeit [w:] Nicht nur Bauhaus. Netzwerke der Moderne in Mitteleuropa / Not just Bauhaus. Networks of Modernity in Central Europe, red. Beate Störtkuhl, Rafał Makała, Berlin-Boston 2020 (Schriften des Bundesinstitutes für Kultur und Geschichte der Deutschen im östlichen Europa, Bd. 77), s. 39-61.

Fischer F[riedrich], Treppenanlage im Hause Frauengasse 9 in Danzig, „Zentralblatt der Bauverwaltung" 1925, Jg. 45, nr 11, s. 126-127.

Friedrich Jacek, Walka obrazów. Przedstawienia wobec idei w Wolnym Mieście Gdańsku, Gdańsk 2018.

Frick Kurt, Danzig stellt sein Stadtbildwieder her. Erneuerung und Umgestaltung von Giebelhäusern durch Architekten Dipl.-Ing. Heinz Bahr, „Deutsche Bauzeitung” 1936, Jg. 70, H. 3, s. 45-52.

Hipp Hermann, Fritz Schumachers Hamburg: Die reformierte Stadt [w:] Moderne Architektur in Deutschland 1900 bis 1950. Reform und Tradition, Hg. Vittorio Magnago Lampugnani, Romana Schneider, Stuttgart [1992], s. 151-174.

Hofer Sigrid, Reformarchitektur 1900-1918. Deutsche Baukünstler auf der Suche nach dem nationalen Stil, Stuttgart-London 2005.

Keyser Erich, Danzig aufgenommen von der Staatl[ichen] Bildstelle, Berlin 1934.

Keyser Erich, Die Baugeschichte der Stadt Danzig, Köln-Wien 1972.

Kießling Martin, Neue Baugedanken im alten Danzig, „Zentralblatt der Bauverwaltung” 1929, Jg. 49, nr 43, s. 693-704.

Kloeppel Otto, Die Wiederherstellung des alten Stadtbildes von Danzig seit der national Erhebung. I. Die Arbeiten des Jahres 1934 (Die Baukunst im Deutschen Osten. Beiträge zu ihrer Gestaltungsentwicklung, Hg. Architekturabteilung der Technischen Hochschule Danzig), [Danzig 1935].

Krückemeyer Thomas, Gartenstadt als Reformmodell. Siedlungskonzeption zwischen Utopie und Wirklichkeit, Siegen 1997.

Lampmann Gustav, Die Krise im Denkmal- und Heimatschutz. Zur Tagung des Bundes für Denkmalpflege und Heimatschutz vom 3. bis 8. September 1928 in Würzburg und Nürnberg, „Zentralblatt der Bauverwaltung” 1928, Jg. 48, H. 40, s. 641-644.

Lindau Friedrich, Fischer, Friedrich Wilhelm Heinrich [w:] Saur. Allgemeines Künstler-Lexikon. Die bildenden Künstler aller Zeiten und Völker, Hg. Günter Meißner, Bd. 40, München 2004, s. 333. 
Ewa

Barylewska-

-Szymańska

Lippky Gerhard, Volmar Erich [w:] Altpeußische Biographie, Hg. Erich Bahr, Gerd Brausch, Bd. 4, Marburg 1984, s. 1299.

Lorens Piotr, Rozwój urbanistyczny Gdańska w latach 1918-1945 [w:] 100-lecie nowoczesnej urbanistyki w Gdańsku, red. Małgorzata Postawka, Piotr Lorens, Gdańsk 2009, s. 72-104.

Makała Rafał, Nawiązania do tradycji nowożytnej w ceglanej architekturze wczesnomodernistycznej północnych Niemiec, „Porta Aurea” 2018, t. 17, s. 94-111.

Mebes Paul, Um 1800. Architektur und Handwerk im letzten Jahrhundert ihrer traditionellen Entwicklung, Bd. 1-2, München 1908.

Muthesius Hermann, Das englische Haus, Bd. 1-3, Berlin 1903-1904.

Muthesius Hermann, Das Fabrikdorf Port Sunlight bei Liverpool, „Zentralblatt der Bauverwaltung" 1899, Jg. 19, s. 133-136, 146-148.

Omilanowska Małgorzata, Defortyfikacja Gdańska na tle przekształceń miast niemieckich w XIX wieku [w:] Budowanie nad Battykiem. Studia z architektury i sztuki Gdańska, Pomorza i Żmudzi, Gdańsk 2018, s. 8-41.

Posener Julius, Berlin auf dem Wege zu einer neuen Architektur. Das Zeitalter Wilhelms II., München, New York 1995 [wyd. 2].

Reichertz Willibald, Ostdeutsche als Dozenten an der Technischen Hochschule Hannover (1831-1956), „Ostdeutsche Familienkunde” 2007, Jg. 55, H. 3, s. 109-120.

Reuther Hans, Fischer, Friedrich Wilhelm Heinrich [w:] Neue Deutsche Biographie, Bd. 5, Berlin, s. 185, http://www.deutsche-biographie.de/ppn135989744.html [dostęp: 12.06.2021].

Rozmarynowska Katarzyna, Z działalności i twórczości architekta Hugona Althoffa - senatora Wolnego Miasta Gdańska w latach 1928-1933 [w:] 100-lecie nowoczesnej urbanistyki w Gdańsku, red. Małgorzata Postawka, Piotr Lorens, Gdańsk 2009, s. 59-71.

Schmitz Herrmann, Die Bautätigkeit Fischers im Freistaate Danzig, „Zeitschrift für bildende Kunst" 1924/1925, Jg. 58, H. 7, s. 134-139.

Schollmeier Axel, Gartenstädte in Deutschland. Ihre Geschichte, städtebauliche Entwicklung und Architektur zu Beginn des 20. Jahrhunderts, Münster 1990.

Schütz Paul, Kennst Du Deine Kirche? Was die Brösener St. Antonius-Kirche erzählt, Danzig [1926].

„Staatsanzeiger für Danzig für 1921” 1922, nr 65, s. 311.

Stephan Regina, Hermann Muthesius' Studien in England und „Das englische Haus” 1904 [w:] 100 Jahre Deutscher Werkbund 1907/2007, Hg. Winfried Nerdinger, München 2007, s. 23-24.

Störtkuhl Beate, Wieżowce we Wrocławiu a "gorączka wysokościowców” w Niemczech lat dwudziestych [w:] Wieżowce Wrocławia, red. Jerzy Ilkosz, Beate Störtkuhl, Wrocław 1997, s. 13-25.

Szczerski Andrzej, Wzorce tożsamości. Recepcja sztuki brytyjskiej w Europie Środkowej około roku 1900, (Ars vetus et nova, t. 10, red. Wojciech Bałus), Kraków 2002.

Voigt Wolfgang, Vom Ur-Haus zum Typ. Paul Schmitthenners, deutsches Wohnhaus und seine Vorbilder [w:] Moderne Architektur in Deutschland 1900 bis 1950. Reform und Tradition, Hg. Vittorio Magnago Lampugnani, Romana Schneider, Stuttgart [1992], s. 245-265.

Volmar Erich, Danzigs Bauwerke und ihre Wiederherstellung. Ein Rechenschaftsbericht der Baudenkmalpflege, Danzig 1940. 
Wünsch Carl, Fischer Friedrich Wilhelm Heinrich [w:] Altpreußische Biographie, Bd. 3, Hg. Kurt Forstreuter, Fritz Gause, Marburg am Lahn 1975, s. 904.

Zacharias Rainer, Bernhard Schmid (1872-1947). Preußischer Landeskonservator und Baumeister der Marienburg [w:] Das Preußenland als Forschungsaufgabe. Eine europäische Region in ihren geschichtlichen Bezügen. Festschrift für Udo Arnold zum 60. Geburtstag gewidmet von den Mitgliedern der Historischen Kommission für ostund westpreußische Landesforschung, Hg. Bernhart Jähnig, Georg Michels (Einzelschriften der Historischen Kommission für ost- und westpreußische Landesforschung, Bd. 20), Lüneburg 2000, s. 689-714.

\section{Opracowania internetowe:}

Fischer Friedrich, http://kulturportal-west-ost.eu/biographien/fischer-friedrich-2 [dostęp: 12.06.2021].

Fischer, Friedrich Wilhelm Heinrich, http://www.glass-portal.privat.t-online.de/hs/a-f/ fischer_friedrich.htm [dostęp: 12.06.2021].

\section{Activities of architect Friedrich Fischer (1879-1944) in Gdańsk and Sopot}

The person of the architect Friedrich Fischer has been somewhat forgotten, even though he played a meaningful role in the beginnings of the existence of the Free City of Gdańsk as its first conservator and the first head of the Ground Construction Office.

Before and during WW I Fischer worked privately as an architect, mostly in the Gdańsk and Sopot area, and among chosen projects one located in Wrzeszcz, in Uphagena Street, as well as the architect's own house at 30 Stefana Żeromskiego Street in Sopot can be named.

F. Fischer was also a scholar who obtained a doctorate in 1910 and prepared a postdoctoral thesis, as well as a lecturer at the Department of Architecture at the Technical University (until April 1925).

In 1918, he became involved in building administration, carrying out projects for the Housing Estate Office, of which he was the head. He created designs of the street now known as Hallera Street in Wrzeszcz and plans of green areas on former fortification grounds. He also initiated works on the plan of Great Gdańsk, eventually known as the 'Althoff plan'. In 1923-1925, he was the head of the Ground Construction Office.

From this period his designs of the first version of the school in Pestalozziego Street in Wrzeszcz and the unrealised fair building in Gdańsk are known. He designed the completed housing estates in today's Zbyszka z Bogdańca and Dubois Streets in Gdańsk-Wrzeszcz as well as several churches for the Catholic community of the Free City of Gdańsk: St Anthony's Church in Gdańsk-Brzeźno, the Church of Our Lady of Sorrows in Głęboka Street in Gdańsk- Knipawa, and the Church of Christ the King in the small town of Piekło, in the former Wielkie Żuławy District.

Fischer was active as Conservator of Architectural Monuments for four years. During this period the function of Conservator of Historical Monuments was merged with the function of the head of the Ground Construction Office. During his service as conservator the preservation of the historical form of the city became a priority. 
Ewa The model of proceedings in the Free City area established by Fischer constituted Barylewskaan important point of reference in the following years. He was also involved in the preparation of the Preservation of Historical Monuments Act proclaimed in 1923.

In March 1925, Fischer moved to Hannover, where he became associate professor specialising in medieval architecture. He remained in that city and at its university until his death.

Tłumaczenie Dorota Powirska 